\title{
LOS APOYOS SOCIALES DE LOS MOVIMIENTOS Y REGÍMENES FASCISTAS EN LA EUROPA DE ENTREGUERRAS: 75 AÑOS DE DEBATE CIENTÍFICO*
}

\author{
por
}

\author{
EduARdo GonZÁlez CALleja
}

Instituto de Historia, CSIC

RESUMEN: En este ensayo se tratan de esbozar las líneas esenciales del peculiar proceso de construcción y deconstrucción a que han sido sometidas las interpretaciones "clásicas» sobre los apoyos sociales del fascismo elaboradas en las cuatro décadas posteriores a la Gran Guerra. Desde fines de los años sesenta se constató que las tres grandes corrientes o líneas de interpretación del fascismo (la de matriz liberal, la de origen radical-democrático y las diversas concepciones de inspiración marxista) babian entrado en una crisis epistemológica que condujo de la teorización a la "bistorización» del fascismo. Ello ba supuesto que la bistoriografía de los últimos años haya abordado una amplia tarea de revisión de la naturaleza del apoyo social a los movimientos y regímenes fascistas y autoritarios del período de entreguerras. Una labor de crítica que, si bien no ba desembocado en la consolidación de ningún gran paradigma alternativo, si ha trazado un mapa de los temas, problemas y debates que constituyen el estado de la cuestión sobre el fascismo en este comienzo de siglo.

Palabras Clave: Fascismo. Autoritarismo. Análisis Sociológico. Historiografía. Siglo $\mathrm{XX}$.

ABSTRACT: The object of this essay is to underline the essential elements of the peculiar process of construction and deconstruction in the 'classic' interpretations of the social basis of fascism established in the four decades after the First World War. We describe bow at the end of the sixties the three main interpretations of fascism (regarding its liberal origins, its radical democratic origins, Marxist interpretations respectively) experienced an epistemological crisis that led from theory to the bistoricising of

* El presente trabajo es una versión, notablemente ampliada, de nuestra aportación al V Seminario de Estudios Históricos Hispano-Británicos, La transición a la sociedad de masas, celebrado en Valencia los días 29 y 30 de octubre de 1999. 
fascism. In recent years, historians have begun an extensive revision of their views on the nature of the social basis of fascist and authoritarian movements and regimes during the inter-war period. This critical approach has not yet consolidated an alternative paradigm or interpretation but has created a new variety of themes, problems and debates, forming the present state of our knowledge on fascism in the beginning of the twenty-first century.

KEY WORDS: Fascism. Authoritarianism. Sociological Analysis. Historiography. $\mathrm{XX}^{\text {th }}$ Century.

Ernest Mandel señaló en una ocasión que escribir la historia del fascismo implicaba también dar cuenta de los análisis teóricos a que ha sido sometido como gran hecho político contemporáneo ${ }^{1}$. Pero el estudio del fascismo, y en concreto de sus bases de apoyo, sigue siendo un territorio marcado por el estupor. Desde la misma aparición de los «movimientos de camisas» sobre la plaza pública, los científicos sociales abordaron su valoración con un apasionamiento beligerante que, en muchos casos, se desbordó hacia el dogmatismo y el prejuicio. Posiblemente, ningún otro acontecimiento del siglo XX ha mantenido por tan largo tiempo un componente polémico de tal magnitud, hasta el punto de inducir a una o dos generaciones de investigadores a «tomar partido» en condiciones de marcada implicación personal. Estos especialistas se plantearon el qué, el cómo y el porqué del fascismo como parte integrante de su propia experiencia vital, tan llena de zozobra como de frustración o de remordimiento por no haber sabido entender y combatir un fenómeno al que caracterizaron sin dudar como un "peligro» o un "problema». No es de extrañar que, con ese talante dominado por la pasión y la ideologización extremadas, el fascismo acabara siendo contemplado bajo luces muy parciales. Durante la posguerra, Hannah Arendt reconoció en su obra sobre el totalitarismo que el estudioso de la época no podía todavía analizar y comprender el fascismo sine ira et studio. Más bien lo contrario: con tendencia al dolor y a la lamentación ${ }^{2}$.

También advirtió Angelo Tasca que «definir el fascismo es, ante todo, escribir su historia». Pero ino es menos cierto que la historia del fascismo es la de los errores, dudas y fracasos de sus adversarios a la hora de caracterizarlo en sus complejas manifestaciones?. Las teorías del fascismo podrían ser interpretadas, en gran parte, como la justificación, el diagnóstico o el paliativo de esas derrotas. De hecho, el propósito de las interpretaciones coetáneas del fascismo nunca fue quedar confinadas en el ámbito académico, sino proporcionar las teorías y los instrumentos de conocimiento necesarios para informar, argumentar y legitimar una praxis resistencialista política y militar frente a este peculiar fenó-

1 MANDEL, Ernest: El fascismo, Madrid, Akal, 1987, p. 15.

2 ARENDT, Hannah: The Origins of Totalitarianism, Nueva York, Harcourt, Brace, 1951 (ed. castellana, Los orígenes del totalitarismo, 3. Totalitarismo, $2^{\mathrm{a}}$ ed., Madrid, Alianza, 1987, p. 458).

Hispania, LXI/1, núm. 207 (2001) 17-68 
meno o sus manifestaciones adyacentes ${ }^{3}$. Irving Louis Horowitz pudo constatar que las ideologías competidoras del fascismo tendían a interpretarlo desde el punto de vista del apoyo otorgado por unas clases contra las que ellas mismas se habían visto en conflicto histórico. Así, los marxistas de diverso tipo lo explicaron desde el punto de vista de una burguesía que había tolerado o impulsado el «régimen de excepción capitalista», mientras que los liberales lo hicieron en términos de una clase trabajadora en abierta ruptura con la tradición liberal ${ }^{4}$. Parece incluso posible hablar de una identidad retórica común a todas estas interpretaciones gobalizadoras, donde el análisis y la valoración del hecho fascista se realizaron bajo los moldes dramatizadores de un procedimiento penal, en el que estuvieron presentes todos los elementos y partes concurrentes de un "sumario" de esa naturaleza: las víctimas reales o probables del «crimen», los imputados (fueran en grado de autoría inmediata, de complicidad o de inducción), los responsables civiles, y un observador eminente, que sucumbió a la tentación de erigirse a la vez en acusador particular y en tribunal encargado de tipificar la naturaleza del «delito" y de «dictar sentencia» condenatoria.

Este modo tan particular de enfocar el «caso» del fascismo hizo que las diversas tendencias ideológicas tendieran a buscar «coartadas» que evidenciaran posibles circunstancias atenuantes para los errores estratégicos que habían cometido los movimientos políticos antifascistas, y exageraran en contraste las responsabilidades en que, por acción u omisión, habían incurrido las formaciones rivales: el liberalismo hizo hincapié en la deriva radicamente demagógica de la democracia, que derivó en formas totalitarias de dominación sobre unas masas alienadas por la ausencia de canales de representación política de clase; la socialdemocracia y la oposición de izquierda comunista pusieron en solfa la inconsistencia democrática de las fuerzas burguesas y la trayectoria maximalista de la Tercera Internacional, mientras que los comunistas ortodoxos acusaron al conglomerado "socialfascista» de complicidad en el origen y desarrollo de tan horrendo crimen. En la mayor parte de los casos, el «veredicto» formulado estaba cimentado en aproximaciones esencialmente negativas, y pecaba de un crudo reduccionismo. Para los liberales, todo lo que se desviaba de la ortodoxia del pluralismo burgués había tomado la senda autoritaria hacia el totalitarismo o estaba plenamente asentado en él. Para el marxismo, todo lo que estaba en contra del movimiento obrero formaba parte de una reacción de tipo capitalista, y para los incondicionales de la teoría de la modernización, los países que no cumplían las condiciones predefinidas se veían sumidos en el atraso o en vías aberrantes de desarrollo, donde las contradicciones entre sociedad, política, cultura y crecimiento económico arrojaban resultados frecuentemente catastróficos 5 .

3 GRIFFIN, Roger: «Introduction», a International Fascism. Theories, Causes and the New Consensus, Londres, Arnold, 1998, p. 5.

${ }^{4}$ HorowiTZ, Irving Louis: «Fascismo, un movimiento de masas del siglo XX», en Fundamentos de Sociología Política, México, Fondo de Cultura Económica, 1986, p. 270.

s SAZ Campos, Ismael: «Introducció: Repensar el feixisme», Afers, nº 25, 1996, p. 449. 
Muchos representantes de las generaciones intelectuales constituidas en torno al mito resistencial de entreguerras persistieron en contemplar el fascismo como un movimiento esencialmente nihilista, bárbaro, reaccionario, antimoderno, carente de ideología, orientado a la pura acción, y básicamente pequeñoburgués. También incurrieron en una excesiva unilateralidad de análisis, disociando o estudiando los elementos ideológicos, políticos y económicos separados de los sociales. Incluso entre las interpretaciones sociológicas del fascismo -que, a estas alturas, ya pueden ser consideradas como "clásicas»- no es difícil constatar la tentación de ese rígido enfoque monocausal: psicológico en el caso de las teorías de la sociedad de masas, económico en el análisis cominteriano y en las tesis desarrollistas y modernizadoras, y político en las teorías del totalitarismo y del bonapartismo.

Esta patente autolimitación intelectual ha conducido a que cualquier tipología o síntesis fenomenológica que intentase una definición del fascismo haya acabado por considerarse excesivamente general, y por lo tanto escasamente útil para satisfacer los requerimientos del análisis histórico ${ }^{6}$. Cualquier lector interesado en la cuestión habrá podido constatar la crisis epistemológica que, en las últimas tres décadas, ha afectado a las tres grandes corrientes o líneas de interpretación del fascismo: la de matriz liberal que deriva de las teorías del totalitarismo, la de origen radicaldemocrático — según la terminología acuñada por Renzo De Felice- vinculada a las teorías de la modernización, el desarrollo económico y la unificación nacional de algunos países europeos, y las diversas concepciones de inspiración marxista, articuladas en torno a las nociones de lucha de clases y de dominación capitalista ${ }^{7}$. Y sin embargo, estas exégesis «canónicas», elaboradas en las cuatro décadas ulteriores a la Gran Guerra, han constituido el punto de partida imprescindible para abordar, a partir de los años sesenta, una amplia tarea de revisión de la naturaleza del apoyo social a los movimientos y regímenes fascistas. Una labor de crítica que, si bien no ha desembocado en la consolidación de ningún gran paradigma alternativo, sí ha trazado un mapa de los temas, problemas y debates que constituyen el estado de la cuestión sobre el fascismo en este momento.

En las páginas que siguen, trataremos de esbozar las líneas esenciales de ese proceso peculiar de construcción y deconstrucción de las interpretaciones sobre los apoyos sociales del fascismo. Una evolución que parece haber conducido desde la teorización a la «historización» del fascismo. En otras palabras, se han ido abandonando las generalizaciones y las interpretaciones de orden exclusivamente cultural, moral o político y se ha dado prioridad a los análisis no ideológicos, realizados sobre la base de investigaciones de situaciones concretas que de

\footnotetext{
6 HernÁNDEZ SANDOICA, Elena: Los fascismos europeos, Madrid, Istmo, 1992, pp. 20-21.

7 Sobre esta cuestión, vid. in extenso las consideraciones que realiza SAZ, «Repensar el feixisme», pp. 443-473.
}

Hispania, LXI/1, núm. 207 (2001) 17-68 
este modo van despojándose de su anterior carácter excepcional o aberrante . $^{8}$ Pero admitamos que el estudio del fascismo sigue siendo problemático por varios motivos. En primer lugar, supone deducir del experimento originariamente italiano unas estructuras históricas concretas, y asignarlas rango universal. Una cuestión harto polémica, que ha llevado a prestigiosos autores a rehusar explícitamente una lectura comparada del fenómeno?. Una de las enseñanzas que aún podemos extraer de las teorías «clásicas» es la convicción de que el fascismo fue un hecho general en el ámbito de la Europa de entreguerras, aunque con caracteres peculiares en cada partido o movimiento, profundamente vinculados a las raíces de las diversas sociedades nacionales ${ }^{10}$. Sin embargo, los primeros teóricos del fascismo realizaron en ese sentido un trabajo empírico poco sólido, que explica en parte la pobreza en la que se mueve hasta la actualidad el debate teórico y metodológico sobre el estudio de los movimientos y regímenes fascistas en perspectiva comparada.

A lo largo de nuestra exposición tendremos también ocasión de constatar otro hecho de interés: que las grandes corrientes de interpretación social del fascismo surgidas en el período de entreguerras recurrieron a herramientas de análisis ya existentes (la psicología de masas finisecular, el bonapartismo diseccionado por Marx o el imperialismo estudiado por Hobson y Lenin) para intentar explicar un fenómeno ya por entonces difícilmente constreñible en esas categorías. Sin embargo, durante los años de posguerra, se trató de mantener su vigencia teórica mediante un remozamiento parcial de sus premisas esenciales. En última instancia, todas estas alternativas de interpretación totalizante entraron en declive al ser incapaces de romper con un viejo cliché: el protagonismo casi exclusivo de un factor social amorfo (sea la pequeña burguesía en crisis, las masas alienadas o los sectores menos dinámicos de una sociedad en cambio acelerado), susceptible de ser manipulado a voluntad por unas élites que ignoran o desprecian sus intereses sociales o económicos trascendidos en formulaciones culturales e ideológicas propias. Esta ardua tarea de reintegración del «sujeto fascista» será la que abordarían a partir de los años sesenta las diversas tendencias que pueden ser calificadas como «revisionistas».

8 Mason, Tim: "Què se n'ha fet, del "feixisme"?, Afers, n² 25, 1996, p. 480.

9 Los ejemplos más señeros son los de DE FELICE, Renzo: Intervista sul fascismo, a cura di Michael A. Ledeen, Bari, Laterza, 1985, pp. 86-88 y BRACHER, Karl Dietrich: Zeitgeschichtlichen Kontroversen. Um Totalitarismus, Faschismus, Demokratie, Munich, Piper, 1976 (ed. castellana: Controversias de bistoria contemporánea sobre fascismo, totalitarismo y democracia, Barcelona/Caracas, Alfa, 1983).

${ }^{10}$ De Felice, Renzo: Le interpretazioni del fascismo, Bari, Laterza, 1989, p. VIII (ed. castellana: El fascismo: sus interpretaciones, Buenos Aires, Paidós, 1976) y CollotTI, Enzo: Fascismo, fascismi, Florencia, Sansoni Editore, 1989, p. 6. 


\section{LA COARTADA DE LA ALIENACIÓN: LAS TEORÍAS LIBERALES SOBRE LA SO- CIEDAD DE MASAS Y EL TOTALITARISMO}

Desde que Benedetto Croce definió el fascismo como una enfermedad intelectual y moral, las primeras interpretaciones elaboradas desde el sesgo del liberalismo lo condenaron como un epifenómeno negativo, carente de una individualidad que pudiera justificar el interés historiográfico ${ }^{11}$. El fascismo aparecía como una dictadura demagógica, que había intervenido de forma absoluta sobre un cuerpo social enajenado bajo la forma de masa. Pero si existe algún fenómeno característico del "espíritu» de la sociedad occidental durante el período de entreguerras es el desarrollo de la política y de la cultura de masas. La concepción de la sociedad moderna como una sociedad masificada ha constituido desde entonces uno de los principales leit motiv para el estudio de los movimientos sociales, partidos y regímenes políticos contemporáneos.

Ya desde fines de siglo, entre los cenáculos intelectuales del liberalismo europeo se fue extendiendo una sensación de acoso y asfixia ante el protagonismo de las multitudes, que en la arena ideológica y política derivó hacia dos actitudes ambivalentes. Por un lado, los sectores más elitistas percibieron los mecanismos de socialización masiva como un desafío al individualismo y a los principios racionalizadores que Weber encontraba característicos de la cultura occidental. Por otro lado, se veía la necesidad de canalizar de alguna forma ese impulso a través del fomento de mitologías políticas democráticas y de nuevas alternativas a la planificación y a la organización burocrática de la sociedad.

La teoría de masas fue reasumida a fines de los años veinte por Max Scheler, y con referencias sociales y políticas más explícitas a la crisis de la democracia liberal, por José Ortega y Gasset y por Karl Mannheim. Para este último, las masas eran el resultado de la disgregación del sistema de clases, única estratificación social y política posible en las naciones-estado europeas. Esas masas eran manipuladas en sentido revolucionario por intelectuales ajenos a los grupos liberal-burgueses y socialistas, conduciendo a la implantación de dictaduras

11 CROCE, Benedetto: Scritti e discorsi politici, 1943-1947, Bari, Laterza, 1963, 2 vols. Sobre esta cuestión, vid. GENTILE, Emilio: «Fascism and Italian Historiography: In Search of an Individual Historial Identity", Journal of Contemporary History, vol. XXI, 1986, p. 180. En su época, el exjerarca nazi RAUSCHNING, Hermann: Der Revolution des Nibilismus, Zürich, Europa Verlag, 1938 caracterizó el fascismo como un movimiento anticonservador, antiburgués y anticapitalista de raíz anarquizante. Es bien sabido que la historiografía alemana de posguerra argumentó que el nazismo era la culminación de una crisis moral de la sociedad europea, no una «enfermedad» exclusivamente alemana. En concreto, MEINECKE, Friedrich: Die Deutsche Katastrophe. Betrachtungen und Erinnerungen, Zürich, E. Brockhaus: 1946 hablaba de «la historia de la degenerescencia de la humanidad alemana». Vid. también RiTTER, Gerhard Albert: Die Dämonie der Macht, Munich/Stuttgart, Leibniz Verag, 1948 y Europa und die Deutsche Frage. Betrachtungen über die geschichtliche Eigenart des Deutschen Staatsdenkens, Munich, F. Bruckmann, 1948 (ed. inglesa: The German Problem: Basic Questions of German Political Life, Past and Present, Columbus, Ohio State University Press, 1965; ed. ampliada: Das Deutsche Problem. Grundfragen Deutschen Staatslebens gestern und heute, Munich, Oldenbourg, 1966). 
totalitarias que repudiaban la Historia y se basaban en un modelo de racionalización puramente funcional, es decir, dirigida y coordinada con una meta o con un fin determinado ${ }^{12}$. Con tales antecedentes, no es de extrañar que, en los años inmediatamente anteriores y posteriores a la guerra, las hipótesis vinculadas a la sociedad de masas fueran empleadas por la Escuela de Frankfurt para explicar desde un sesgo psicológico freudiano-marxista la supuesta docilidad del proletariado moderno ante ciertos procesos de dominación del capitalismo avanzado, y para estudiar la conformación de una "personalidad autoritaria» que representaba el principal rasgo de la estructura caracterial de lo que Reich describió como «la pequeña burguesía sublevada»: los millones de funcionarios privados y públicos, los comerciantes de la clase media y los granjeros de las clases medias e inferiores que apoyaron al fascismo ${ }^{13}$. Este grupo entendió el fascismo como el reflejo de la infraestructura económica en la estructura psicológica autoritaria de miembros individuales o de grupos sociales como la clase media frustrada tras la guerra. Incluso se pretendió ver una conexión entre la irracional tendencia a la autodestrucción y el fracaso en tratar con la realidad circundante típicos de las dictaduras fascistas y el crecimiento de los grupos medios como fuerza política autónoma bajo el fascismo ${ }^{14}$. Sin embargo, al reducir a éste a mecanismos de simple psicología colectiva, las tesis defendidas por la Escuela de Frankfurt proporcionaron una explicación incompleta, y a la postre instisfactoria, del universo de motivaciones (cálculos, intereses, aspiraciones, identidades, etc.) que impulsaron a tan variados grupos sociales a adherirse $o$ a repudiar el fascismo.

El paradigma de la sociedad de masas fue recuperado y reformulado en los años cuarenta y cincuenta de la mano de la teoría funcionalista norteamericana, en perfecta conjugación con las teorías del totalitarismo. Las interpretaciones del totalitarismo proporcionaban una visión adecuada del funcionamiento del sistema político de la que carecía la teoría de la sociedad de masas. Masas y Estado totalitario aparecían como factores indisociables del funcionamiento de un sistema donde el individuo, sin mediaciones sociales o políticas con el Estado, quedaba inerme ante un poder invasivo. Además de su capacidad engloba-

12 Mannherm, Karl: Ideologie und Utopie, Bonn, Friedrich Cohen, 1929 (ed. inglesa, Ideology and Utopia, Nueva York, Harcourt Brace, World, 1936; ed. castellana, Ideología y utopía, México, Fondo de Cultura Económica, 1987, pp. 125-129).

13 ReICH, Wilhelm: Die Massenpsychologie des Faschismus, Zurich, Sex-Pol Verlag, 1933 (ed. castellana, La psicología de masas del fascismo, México, Eds. Roca, 1973, p. 15). Vid. también ADORNO, Theodor W., Fraenkel-Brunswig, Else, Levinson, D.J. y NevitT SANFORD, E.: The Authoritarian Personality. Studies in Prejudice, Nueva York, Harper and Brothers, 1950; HoRKHEIMER, Max: Studien über Autorität und Familie, París, Félix Alcan, 1936 y Fromm, Erich: Die Furcht vor der Freibeit, Zurich, Steinberg, 1945 (ed. inglesa, Escape from Freedom, Nueva York, Holt, Rinehart \& Winston, 1941 y ed. castellana, El miedo a la libertad, Buenos Aires, Paidós, 1957).

${ }^{14}$ BLANKe, B.: «Thesen zur Faschismus-Diskussion», Sozialistische Politik, no 3, octubre 1969, pp. 55 y 62.

Hispania, LXI/1, núm. 207 (2001) 17-68 
dora de realidades políticas no acordes con el paradigma pluralista de la democracia liberal, el concepto de totalitarismo aportaba el adecuado contrapunto polémico a la interpretación soviética del fascismo, ya que escamoteaba el análisis clasista allí donde la teoría marxista ortodoxa situaba exclusivamente la oposición de identidades, intereses y medios de acción propia de la lucha de clases.

Los trabajos de Hannah Arendt y de Friedrich y Brzezinski inauguraron los estudios académicos sobre el totalitarismo, que hegemonizaron la ciencia política occidental durante los años cincuenta. Pero la obra de Arendt, escrita entre. las fechas clave de 1945 y 1949 (fin de la Segunda Guerra Mundial y comienzo de la Guerra Fría) es mucho más que un estudio sobre el totalitarismo. Éste aparece como la desembocadura de un prolongado declive histórico de la sociedad de clases y del Estado-nación dominados por la burguesía. El totalitarismo, definido como «el permanente dominio de cada individuo concreto en todas y cada una de la esferas de su vida", no sería sino la más reciente de las tres manifestaciones sucesivas de la crisis del liberalismo burgués, junto al antisemitismo y el imperialismo. En realidad, Arendt se centró en estudiar las condiciones psicológicas del hombre moderno en la sociedad industrial (aislamiento, alienación, desvinculación afectiva, atomización...) que explican su militancia en movimientos políticos especializados en formular reclamaciones monolíticas, y cuyos líderes recurren a modernos conocimientos científicos y tecnológicos para reducir a los individuos al aislamiento moral a través de la destrucción de lo que Durkheim llamó «sociedades intermedias», y controlarlos mediante procedimientos arbitrarios de carácter terrorista ${ }^{15}$. Este tipo de movimientos no pretenden organizar los intereses de las clases o de los ciudadanos, como los partidos de los regímenes liberales clásicos, sino que se basan en una «nueva y aterradora» solidaridad negativa: la pura fuerza numérica de las masas formadas por personas neutrales y políticamente indiferentes, pero que en determinadas circunstancias han adquirido el apetito de la organización política, y que no se mantienen unidas por la conciencia de un interés común, sino por necesidades más primarias, como la búsqueda de seguridad personal o de la identidad comunitaria. La victoria del fascismo, según Arendt, radicó en su capacidad para apoderarse de los instrumentos que habían activado la movilización de las masas, expresando su capacidad de llegar al poder no mediante un golpe de Estado, sino a través del consenso manipulado de las multitudes, dirigidas hacia un único objetivo político: la unidad entre el pueblo y la nación. La naturaleza y el alcance de ese pretendido consenso siguen siendo los aspectos más polémicos de los estudios sobre el fascismo.

Aunque planteó cuestiones de gran trascendencia teórica, como el proceso de crisis sociopolítica previo al ascenso del fascismo, los rasgos psicológicos de las masas y los mecanismos del "consenso» dentro de los sistemas totalitarios,

is ARENDT: Los orígenes del totalitarismo, vol. III, pp. 485 y 489. 
el ensayo de Arendt adolece de una serie de limitaciones básicas a la hora de aplicar sus hallazgos al estudio de las bases sociales del fascismo. En primer lugar, se detuvo de forma preferente en la dinámica del poder desencadenada en el seno de los movimientos totalitarios durante su fase de ascenso, dejando en un segundo plano su evolución en los regímenes ya establecidos. En segunda instancia, planteó una visión teleológica del totalitarismo como un «experimento para organizar la gente para fines últimos», eliminando la espontaneidad y transformando la personalidad individual y la psicología colectiva en elementos pasivos, susceptibles de ser manipulados y controlados por un Estado omnipotente. Por último, Arendt no consiguió elaborar una teoría clara del totalitarismo, y su argumento esencial para explicar el desarrollo del mismo (la completa desaparición de las clases y su sustitución por una sociedad de masas) resulta evidentemente falso, como veremos más adelante ${ }^{16}$.

Quizás de forma más evidente que Arendt, Friedrich y Brzezinski estudiaron los regímenes en su esencia antidemocrática, elaborando un modelo hipotético de gobierno despojado de toda referencia social e histórica concreta que arrojase luz sobre su dinámica interna, de sus funciones y fines políticos, o de las condiciones socioeconómicas en que se desarrollaron. La enumeración que hicieron de las seis características básicas de lo que definieron sintomáticamente como «síndrome totalitario» ${ }^{17}$ incidía exclusivamente en los aspectos políticos e ideológicos del fenómeno, en especial la estructura, las instituciones y la técnica del poder. Lo más notable es su cuidadosa separación de los modelos totalitario (que en su aspecto histórico consideraron único e irrepetible) y autocrático, y la integración de la Italia fascista dentro de este último concepto.

Con su estilo de análisis fenomenológico y puramente formal, los estudios sobre el totalitarismo acabaron por transformarse en análisis de patología política con designios marcadamente ideológicos. El concepto estático y estructural del totalitarismo no era capaz de conciliar en la teoría todas las características de regímenes tan diversos en estructura, función social, ideología, acción política y evolución histórica como fueron el comunismo soviético y el fascismo. Confunden forma y contenido, la apariencia exterior de los sistemas de gobierno y su esencia. Con ello, el fascismo perdía su especificidad histórica y se transformaba en una posibilidad inherente a la estructura misma de la sociedad

16 KerShaw, Ian: The Nazi Dictatorship. Problems and Perspectives of Interpretation, Londres, Edward Arnold, 1985 (ed. francesa, Qu'est-ce que le nazisme?. Problèmes et perspectives interprétation, París, Gallimard, 1992, p. 62).

17 1) Ideología oficial que cubre todos los aspectos de la existencia humana; 2) Partido único de masas guiado por un dictador, organizado de forma jerárquica y superior a la burocracia estatal o confundido con ella; 3) Sistema de control policial y terrorista; 4) Monopolio tecnológico casi completo de control de los medios de comunicación; 5) Monopolio similar de todo el aparato bélico dirigido hacia la lucha armada, y 6) Control y dirección central de la economía (FruEDrich, Carl J. y BRZEZINSKI, Zbigniew K.: Totalitarian Dictatorship and Autocracy, Nueva York, Praeger, 1956, pp. 9-10. $2^{a}$ ed., revisada por Friedrich, en Cambridge, Harvard University Press, 1965). 
industrial en cuanto sociedad de masas ${ }^{18}$. En realidad, como ya señaló Mosse, «la teoría del totalitarismo contempla el mundo exclusivamente desde un punto de vista liberal», valorando el ejercicio del poder, pero infravalorando los diferentes desarrollos históricos, ideologías y culturas de base. Algunos estudiosos de extrema izquierda han señalado malévolamente que el concepto de totalitarismo y la antigua definición oficial del fascismo formulada por la Tercera Internacional guardan un cierto nivel de similitud: si de un lado se asimilan comunismo y fascismo, del otro se ignoran las diferencias cualitativas entre la democracia parlamentaria burguesa y el sistema fascista ${ }^{19}$.

$\mathrm{Al}$ no preocuparse apenas por la fase previa a la conquista del poder, este producto intelectual de la Guerra Fría acordó una importancia excesiva al carácter pretendidamente monolítico de los sistemas totalitarios. Tendía a eliminar la complejidad de las tensiones internas características de los movimientos y regímenes fascistas, y a reducir a éstos a una contradicción relativamente simple entre masas y democracia ${ }^{20}$. Confundía la destrucción de toda organización política autónoma con la destrucción de las clases cuando, al contrario de lo que argumenta la teoría de la sociedad de masas, en los países donde se afirmó el fascismo el sistema de estratificación social era bastante más rígido, el peso de las estructuras tradicionales era más fuerte y el grado de atomización menor que en otras realidades donde el fascismo no tuvo tanto arraigo.

La legitimidad del concepto de totalitarismo descansaba en la aceptación de los valores de la democracia occidental y en el mantenimiento de una dicotomía en entre formas de gobierno «abiertas» y "cerradas». No es de extrañar que, a partir de la détente de los años sesenta, este modelo entrase en crisis por la críticas procedentes de sectores marxistas, pero también de las nuevas interpretaciones liberales, que destacaron los contrastes políticos que se producían el seno de sociedades estructuradas y sostenidas por constelaciones de fuerzas muy diferentes.

\section{LA COARTADA DE LA INDUCCIÓN: LA TEORÍA DEL ESTADO DE EXCEPCIÓN CAPITALISTA EN LA DOCTRINA DE LA III ${ }^{a}$ INTERNACIONAL}

Si en un principio el fascismo fue interpretado como la manifestación de características peculiares de la sociedad italiana o como un hecho histórico casi accidental, fue el marxismo en sus diversas tendencias quien propuso las primeras interpretaciones generales, no vinculando ya el fenómeno a una realidad nacional concreta o a un período histórico excepcional, sino a un tipo genérico

\footnotetext{
18 SACCOMANI, Edda: Le interpretazioni sociologiche del fascismo, Turín, Loescher Editore, 1977, p. 41.

19 KIIEM, Kurt, KAMmLER, Jörg y GRIEPENBURG, Rüdiger: «Introducción, Sobre la teoría del fascismo", en Fascismo y capitalismo. Teorías sobre los orígenes sociales y la función del fascismo, Barcelona, Eds. Martínez Roca, 1972, pp. 20-21.

${ }^{20}$ LAClAU, Ernesto: «Fascismo e ideología», en Política e ideología en la teoría marxista. Capitalismo, fascismo y populismo, $3^{\text {a }}$ ed., Madrid, Siglo XXI, 1986, p. 95.
}

Hispania, LXI/1, núm. 207 (2001) 17-68 
de sociedad (la capitalista) en un momento determinado de desarrollo, y aportando una interpretación estrictamente de clase. Las valoraciones marxistas del fascismo son múltiples, e incluso divergentes en su etiología, diagnóstico y salida. Pero el análisis marxista mantiene un rasgo discursivo común: el presentar el fascismo como una forma de poder totalitario, resultado de un proceso contrarrevolucionario impulsado por los intereses de un capitalismo monopolista en crisis.

Buena parte de la favorable acogida obtenida en su época por la interpretación marxista ortodoxa radicó en que su explicación del fascismo era global, simple, histórica y dinámica ${ }^{21}$, y en la destreza con que el comunismo soviético supo caracterizar al fascismo como la perfecta encarnación del enemigo que cerraba el camino hacia nuevas etapas de progreso de la Humanidad. El fascismo aparecía como un tipo de contrarrevolución primero, y de régimen de excepción después, fruto de una crisis política concreta del capitalismo, la cual alumbraba a su vez una determinada forma de dictadura.

El análisis comunista ortodoxo sobre las bases sociales del fascismo se puede rastrear desde la primera andadura del régimen de Mussolini, y se caracterizó desde el principio por un burdo esquematismo. El IV Congreso de la Comintern (1922-23) explicó el fascismo como un fenomeno netamente contrarrevolucionario, propio de países que habían accedido tardíamente al desarrollo capitalista y que presentaban aún una importante estructura agraria tradicional. Aunque Amadeo Bordiga trató de convencer a los asistentes de que el fascismo no era la expresión mecánica de los intereses de burguesía agraria en oposición a los del capitalismo industrial, sino una reacción propia de sectores diversos de la burguesía y de las clases medias ${ }^{22}$, Zinoviev logró hacer prosperar la tesis de que el fascismo era un fonómeno esencialmente reaccionario que representaba los intereses agrarios en los países atrasados, aunque reconocía la originalidad de ser un movimiento de masas, y aceptaba la posible expansión de esa experiencia a otros países. La ecuación fascismo $=$ reacción burguesa fue duramente cuestionada por Clara Zetkin, quien en el III Plenum de 12-13 de junio de 1923 no dejó de advertir que el fascismo italiano era un movimiento de «los hambrientos, sufrientes y frustrados", de amplia base social (incluido el proletariado), muy distinto de la dictadura de Horthy en Hungría, y que por su peculiar fisonomía social no podía interpretarse como la simple venganza de la burguesía contra el proletariado insurreccional. Del mismo modo, Karl Radek enfatizó en 1923 la necesidad de diferenciar entre varias formas de contrarrevolución: el fascismo como «socialismo de las masas pequeñoburguesas» y otras formas de dictadura abierta de la burguesía. De todos modos, la doctrina de la

${ }^{21}$ AYÇOBERRY, Pierre: La question nazie. Les interprétations du national-socialisme, 1922-1975, París, Seuil, 1979, p. 75.

${ }^{22}$ BORDIGA, Amadeo: «Stato, capitalismo e ceti medi» (informe al IV Congreso de la IC, 16X-1922), en CASUCCI, Constanzo (ed.), Il fascismo. Antologia di scritti critici, Bolonia, Il Mulino, 1982, pp. 405-409.

Hispania, LXI/1, núm. 207 (2001) 17-68 
Comintern siguió evaluando el fenómeno como la última forma de la dictadura burguesa antes del irremisible triunfo del proletariado. Esta minusvaloración del fascismo como un acontecimiento pasajero, síntoma de las tensiones internas de un capitalismo a la defensiva, llevó a su inclusión entre las diversas formas políticas autoritarias de la época (se asignó el apelativo de fascista a todos los regímenes de excepción, desde el de Pilsudski, Horthy o von Seekt al de Primo de Rivera), simplificadas en su referencia a una misma alianza de clases movida por intereses exclusivamente económicos.

En 1928 se asistió a un progresivo replanteamiento de la cuestión fascista que, sin romper con la ortodoxia marcada en las reuniones de la Comintern, trató de cuestionar su supeditación mecánica a los intereses de la clase dirigente. Palmiro Togliatti señaló que el fascismo no era sólo una reacción capitalista para proteger los intereses exclusivos de la burguesía y los sectores agrarios, sino un fenómeno peculiar, ligado a una cierta configuración de las relaciones existentes entre las clases, y no sólo de las dos clases antagonistas en la moderna sociedad industrial. El fascismo sería el sistema de reacción integral más consecuente que habría existido en los países donde el capitalismo ha alcanzado un cierto grado de desarrollo, pero aparecía huérfano de equilibrio político ${ }^{23}$. Aunque en el XII Plenum de septiembre de 1932 negó al fascismo el carácter de movimiento independiente, Togliatti destacó la inestabilidad de esa alianza, ya que tras la conquista del poder el partido mussoliniano se veía obligado a hacer la política del capital financiero e industrial, en detrimento de los intereses de gran mayoría de la población trabajadora, y agudizando de ese modo las contradicciones con su base social de apoyo, sobre todo la pequeña burguesía productiva.

Sin embargo, la interpretación canónica que prevaleció fue la Dimitrov, cuya definición, esbozada en el XIII Plenum del Comité Ejecutivo de la Tercera Internacional celebrado a fines de 1933, tenía ya todos los ingredientes teóricos que hacen reconocible su análisis del fascismo:

«... Dictadura terrorista declarada de los elementos más reaccionarios, más imperialistas del capital financiero. El Fascismo trata de asegurar una base de masas para el capital monopolista entre la pequeña burguesía, apelando al campesinado, artesanos, empleados y burócratas que se han visto afectados en su curso normal de vida, y particularmente a los elementos desclasados de las grandes ciudades, e incluso tratando de penetrar en la clase obrera» 24 .

En su famoso informe presentado en el VII Congreso de la Comintern (1935), Dimitrov contempló el fascismo como una forma estatal que represen-

${ }^{23}$ ERCOLI (seud. de Palmiro TOGLIATtI): «Grossa e piccola borghesia» (1928), publicado con el título "A proposito del fascismo", en Società, año VIII, ${ }^{\circ} 4$, diciembre 1952, pp. 591-613, y cit. por CASUCCI: Il fascismo. Antologia di scritti critici, pp. 411-428, esp. pp. 416-417.

${ }^{24}$ Cit. en GRIFFIN: International Fascism, p. 59.

Hispania, LXI/1, núm. 207 (2001) 17-68 
taba los intereses contradictorios de diversas clases, trascendidos a nivel institucional por el partido y el Estado fascistas ${ }^{25}$. Con todo, se rechazó explícitamente la tesis «bonapartista», expuesta desde el «austromarxismo» y el comunismo heterodoxo alemán por Otto Bauer o August Thalheimer, del fascismo como forma de poder autónoma de la burguesía y del proletariado. Todo lo más, se reconoció que el fascismo y su dictadura, a pesar de salvaguardar «el poder del capital financiero", no se limitaban a la mera sustitución de un gobierno burgués por otro de excepción, sino que suponían un cambio en la forma de Estado que implicaba un nuevo equilibrio de fuerzas sociales.

Con los requerimientos de la incorporación de amplios sectores de la burguesía a la lucha antifascista impuestos por la estrategia frentepopulista impulsada por la Comintern desde su VII Congreso, el análisis social del fascismo acabó por simplificarse hasta la caricatura. Del mismo modo que la autonomía relativa del Estado fascista y la movilización de masas que precedió a su advenimiento tendieron a ser minusvalorados, el análisis de su compleja realidad social se redujo a una contradicción fundamental: la del capital monopolista y sus lacayos con el resto de la sociedad ${ }^{26}$. Con ello, el fascismo aparecía como la expresión política de un sector cada vez más reducido de intereses, hasta desembocar en el conocido cliché dimitroviano de la dictadura directa del capital monopolista, que se aplicó en la posguerra a cualquier tipo de régimen capitalista autoritario, como las dictaduras de la Europa meridional o del Cono Sur latinoamericano.

Sin embargo, no todas las interpretaciones emanadas de la ortodoxia comunista pecaban del mismo esquematismo. El análisis gramsciano de las fuerzas sociales en presencia en la escena política italiana de posguerra dibujaba un fascismo mucho más complejo en sus ámbitos de socialización rural y urbana. Aunque describa el movimiento fascista como la manifestación de la lucha de la burguesía contra los trabajadores en general, y en particular de la burguesía rural contra las asociaciones de trabajadores agrícolas ${ }^{27}$. Gramsci distinguía entre los apoyos y las alianzas sociales del fascismo-movimiento y del fascismorégimen. El primero se nutría de la pequeña burguesía urbana y de una nueva burguesía agraria - los nuevos intermediarios- surgida de las transformaciones de la propiedad rural en algunas regiones como la Emilia, que encontraron su fermento de unidad ideológica y organizativa en las formaciones militares en las que revivió la tradición guerrera del arditismo. El fascismo-régimen aparecía como la última encarnación de la pequeña burguesía rural y urbana, sierva del

25 Dimitrov, Georgi: «La ofensiva del fascismo y las tareas de la Internacional Comunista en la lucha por la unidad de la clase obrera contra el fascismo", en Fascismo, democracia y frente popular. VII Congreso de la Internacional Comunista, México, Cuadernos de Pasado y Presente, $\mathrm{n}^{\circ} 76,1984$, p. 155.

26 LACLAU: «Fascismo e ideología», p. 97.

27 Discusión en la cárcel de Turi (fines 1930), en GramsCI, Antonio: Sul fascismo, Roma, editori Riuniti, 1974, pp. 432-433. 
capitalismo y de la propiedad agraria ${ }^{28}$. Sin embargo, el fascismo no era una pura reacción, sino un nuevo modo de concebir el proceso de unificación de los intereses de las fuerzas reaccionarias originariamente anticapitalistas, coordinadas por el capitalismo, pero no completamente absorbidas por éste, a través de la creación de un único organismo político que dirigiese conjuntamente el partido, el gobierno y el Estado ${ }^{29}$. De este modo, el fascismo sería, en la concepción gramsciana, el cesarismo propio de las formas capitalistas desarrolladas, alentado por la burguesía como movimiento extralegal y extraestatal.

Como señaló en su día Borkenau, el comunismo ortodoxo elaboró una teoría del fascismo que partió de una definición apriorística de su proceso de formación y triunfo que dificultaba ulteriores investigaciones sociológicas ${ }^{30}$. La interpretación marxista-leninista trató de establecer una relación orgánica, o al menos una estrecha conexión entre fascismo y sistema capitalista. La política resultaba una hechura de la economía y le estaba directamente subordinada, de modo que los movimientos fascistas eran fruto exclusivo de la manipulación burguesa, y ésta venía inducida por la crisis en que se veía sumido el capitalismo en un determinado estadio de su desarrollo. Ello dificultaba la caracterización política precisa del fascismo, que era interpretado como un mero instrumento de combate de la burguesía a despecho de su indudable arraigo de masas, lo que condujo a asignar el apelativo de «fascista» a cualquier régimen de excepción de la época. Se incidió en el carácter monolítico y de clase del Estado fascista, a pesar de la evidencia de su autonomía relativa y del paralelismo e incluso la superposición de las redes de decisión. Todo ello ponía en cuestión la tesis de que la burguesía monopolista actuaba de forma independiente, y permanecía en posiciones hegemónicas en mayor grado que la élite del movimiento fascista.

Efectivamente, el fascismo no era una mera manipulación del capital monopolista, sino un movimiento de masas con un carácter y objetivos propios, que ponía en evidencia una gran crisis de la democracia liberal y del capitalismo. Sin embargo, la interpretación marxista aportó factores plausibles de explicación del fenómeno, como la vulnerabilidad de las élites a las crisis socioeconómicas y políticas, y su predisposición a recurrir al autoritarismo y a la violencia para conjurar toda amenaza «desde abajo».

28 «Il popolo delle scimmie», L'Ordine Nuovo, 2-I-1921, cit. en GraMSCI: Sul fascismo, p. 99.

29 «Il fascismo e la sua politica», tesis del PCI en Lyon (enero 1926), en GrAMSCI: Sul fascismo, pp. 304-305.

30 BORKENAU, Franz: «Zur Soziologie des Faschismus», Archiv für Sozialwissenchaft unf Sozialpolitik, vol. XVIII, febrero 1933, pp. 513-547, reed. en NOLTE, Ernst (ed.), Theorien über den Faschismus, Colonia, Kiepenheuer und Witsch, 1967, pp. 156-181.

Hispania, LXI/1, núm. 207 (2001) 17-68 


\section{LA COARTADA DE LA MEDIACIÓN: EL BONAPARTISMO EN EL ANÁLISIS MARXISTA «ANTICOMINTERIANO»}

A pesar de respetar ciertos panteamientos teóricos esenciales (la caracterización contrarrevolucionaria del fascismo, y su inserción en la agudización de la lucha de clases en un estadio avanzado de la evolución del capitalismo), las diveras tendencias interpretativas de identidad marxista difieren en tres cuestiones esenciales: la cabal determinación del agente fascista (sea la pequeña burguesía, el lumpenproletariado u otros sectores sociales marginales), del inductor (desde un amplio «bloque de poder» a una estrecha fracción de la burguesía industrial), y la peculiar relación que se establece entre ambos actores cuando el fascismo accede al poder.

En un primer momento, los teóricos marxistas adscritos a la socialdemocracia alemana, al "austromarxismo» ${ }^{31}$ o a la oposición comunista de izquierda recurrieron a la doctrina de los padres fundadores para tratar de comprender el peculiar proceso político que se estaba gestando ante sus ojos. La interpretación marxista de los regímenes autoritarios se remontaba a las consideraciones que Marx había realizado sobre el bonapartismo, sobre todo en sus ensayos $E l 18$ Brumario de Luis Bonaparte (1851) y La guerra civil en Francia (1871).

Tanto los "austromarxistas» como un sector del comunismo alemán se inspiraron en estas consideraciones sobre el bonapartismo para abordar su análisis social del fascismo. August Thalheimer, miembro escindido del SPD, e integrante del Comité Central del KPD de 1919 a 1924, partido del que fue expulsado en 1929, no deducía el fascismo por la vía funcional directa de las condiciones de producción en la sociedad capitalista, ni limitaba su papel al de simple agente de la clase burguesa. Consideraba que los Estados de régimen burgués presentaban una tenencia evolutiva general, materializada por una determinada alianza de clases sociales, y que en una constelación conflictiva de poder como la que sufría la sociedad europea de posguerra, las organizaciones políticas burguesas podían apoyar un proceso antidemocrático cifrado en el debilitamiento parlamentario y la autonomización del Ejecutivo, una de cuyas desembocaduras posibles, pero no única, era el fascismo. Éste constituía, según Thalheimer, una forma particular, pero no exclusiva, de la dictadura abierta del capital, y se caracterizaba por el hecho esencial de que el poder político de la burguesía era destruido, y todas las clases sociales se subordinaban políticamente a un poder ejecutivo teóricamente independiente respecto de las clases en conflicto.

Aunque no identificaba fascismo con bonapartismo, Thalheimer argumentó que se trataba de fenómenos políticos que presentaban grandes similitudes: eran formas de Estado que nacían de una situación de «equilibrio catastrófico».

\footnotetext{
${ }^{31}$ Sobre esta última corriente de pensamiento, vid. BoTZ, Gerhard: «Austro-Marxist Interpretation of Fascism», Journal of Contemporary History, vol. XI, n 4, octubre 1976, pp. 129-156.
} 
entre burguesía y proletariado. La caracterización de las clases protagonistas de este conflictivo proceso de independización del Ejecutivo es muy similar al de Marx, para quien el apoyo real del bonapartismo lo constituía la «escoria social» de la burguesía: elementos económica y socialmente desarraigados, libres de vinculaciones ideológicas o de cualquier tipo, e incapaces de actuar como una clase consciente de sí misma. Según Thalheimer, la base del fascismo la formaban los marginados de todas clases: de la aristocracia, de la burguesía, de la pequeña burguesía urbana, del campesinado y del proletariado, tanto el infraproletariado como la aristocracia obrera vinculada a la burocracia de los sindicatos y de los partidos obreros reformistas.

Como podemos comprobar, Thalheimer se ciñó demasiado estrechamente al análisis marxista del bonapartismo, y subestimó las diferencias cualitativas que existían entre ambos fenómenos. Contrariamente al cesarismo, el fascismo no conducía a ningún equilibrio con las clases dominantes, y mientras que el bonapartismo actuaba como «mediador» en los conflictos entre la burguesía y el proletariado, el fascismo buscaba la destrucción de las clases sociales (en especial de la obrera) y la sumisión política de las masas mediante la obtención de un verdadero monopolio político de la autoridad y del Estado. En el bonapartismo se producía una autonomía creciente del aparato del Estado, acompañada de una represión «tradicional» del movimiento revolucionario. En el fascismo esa autonomía del poder estatal iba unida a destrucción sistemática de las organizaciones de la clase obrera ${ }^{32}$.

Mientras que la III ${ }^{\mathrm{a}}$ Internacional identificó de forma simplista la socialdemocracia y el fascismo en su mutua adhesión a la «sociedad burguesa», borrando de ese modo la distinción entre un período «normal» de lucha de clases y la guerra civil que parecía caracterizar el ascenso del fascismo, la oposición comunista trató de explicar que la burguesía no hacía entrar en juego al fascismo sino en el instante en que un peligro revolucionario inminente amenazaba las bases de su predominio social y político. De modo que el fascismo correspondería a «un estado de guerra civil de la sociedad capitalista contra el proletariado insurrecto»33.

A pesar de su estilo frecuentemente polémico, el análisis de León Trotski es comparable en sutileza al de marxistas independientes como Thalheimer o Bauer, y revela una mayor complejidad en su estudio de la estratificación de clases de la sociedad capitalista en relación con el reduccionismo de "clase contra clase» que campaba en los aledaños de la Comintern. Sus deudas con los clásicos del marxismo son evidentes cuando vincula estrechamente las etapas de

32 Thalheimer, August: «Über den Faschismus», en Gegen den Strom. Organ der KPD-Opposition, $n^{\circ}$ s 2-4, 11, 18 y 25-I-1930 (ed. castellana, «Sobre el fascismo», en Fascismo y capitalismo, p. 40). Una evaluación critica de la obra de Thalheimer, en KITCHEN, Martin, "August Thalheimer's Theory of Fascism", Journal of the History of Ideas, vol. XXXIV, $\mathrm{n}^{\circ} 1,1974$, pp. 67-79.

33 TROTSKI, León: L'Internationale Comuniste après Lénine (abril 1930), París, Presses Universitaires de France, 1968 (cit. en L. TrotSKI: El Fascismo, Buenos Aires, Eds. Cepe, 1973, p. 54).

Hispania, LXI/1, núm. 207 (2001) 17-68 
evolución histórica concreta del desarrollo capitalista con las diversas formas del poder político burgués:

«Es necesario distinguir tres fases históricas: los albores de desarrollo capitalista, cuando la burguesía tenía necesidad de medios revolucionarios para realizar sus objetivos; el periodo de florecimiento y maduración del régimen capitalista, durante el cual la burguesía traducía su propio dominio en formas ordenadas, pacíficas, conservadoras, democráticas; finalmente, el declive del capitalismo, cuando la burguesía es impulsada a servirse de métodos de guerra civil contra el proletariado.

Las concepciones políticas típicas de estas tres fases - jacobinismo, democracia reformista (incluida la socialdemocracia) y fascismo- son, en el fondo, concepciones de tendencias pequeñoburguesas» 34 .

Su estudio del nexo entre fascismo y clases sociales presenta fuertes analogías con el esquema de relaciones entre clases que desarrolló Marx en La guerra civil en Francia y El 18 Brumario de Luis Bonaparte. Para Marx, la llegada al poder de Luis Napoleón fue el resultado de un déficit de hegemonía por parte de los sectores revolucionarios, que dio lugar a una reacción de los pequeños propietarios agrarios contra los sectores más dinámicos de la sociedad urbana. Para Trotski, la función contrarrevolucionaria y regresiva en el fascismo la ostentaba la pequeña burguesía afectada por la crisis económica y manipulada por su «hermana mayor». Pero el fenómeno fascista no debía entenderse como una mera proyección política de los intereses de la gran burguesía. La tesis de Trostki advertía que la opción reaccionaria de ésta, como consecuencia de una crisis histórica concreta del sistema capitalista, desembocaba en la instauración de regímenes fascistas cuando los movimientos de esta índole encontraban un terreno propicio en la situación crítica de las clases medias, aparecían en disposición de catalizar los diversos consensos de masa y se transformaban en el instrumento político escogido por la gran burguesía para llevar a término su propia conversión autoritaria ${ }^{35}$.

El fascismo se aprovechaba del equilibrio de las fuerzas sociales concurrentes y de un vacío de hegemonía, productos ambos de una situación en la que la burguesía ya no tenía un papel progresivo que desempeñar, y el proletariado no estaba aún en disposición de conducir a vastos estratos de la sociedad hacia nuevos horizontes de cambio político radical, lo que suponía un reproche evidente a los partidos comunistas y socialdemócratas por su falta de dirección revolucionaria. La pequeña burguesía, que había esperado la revolución social,

${ }^{34}$ TROTSKI, León: «La sola via», en I problemi della rivoluzione cinese e altri scritti su questioni internazionali, 1924-1940, Turín, Einaudi, 1970, pp. 359-360.

35 «Bonapartism, Fascism, and War», último artículo en Bulletin of the Opposition, agostooctubre 1940, p. 130, cit. en TROTSKI: El Fascismo, p. 12. Sobre este proceso, vid. RAPONE, Leonardo: «Movimenti facisti e classi sociali nell'analisi di Lev D. Trotskij», Storia Contemporanea, año VII $\mathrm{n}^{\circ}$ 2, junio 1976, p. 270, y del mismo autor, Trotskij e il fascismo, Bari, Laterza, 1978. 
quedó defraudada por un proletariado incapaz de dotarse de una dirección política del movimiento de masas, y buscó otra salida subversiva, lo que le llevó al enfrentamiento con la clase obrera. Cuando el equilibrio de fuerzas económicas y sociales se rompió, la gran burguesía renunció al ejercicio directo del poder político, y puso en pie una forma superior de centralización del poder ejecutivo para realizar sus intereses históricos, lo que implicaba la destrucción de la mayor parte de las conquistas políticas del movimiento obrero contemporáneo mediante el fomento y apoyo táctico a un movimiento de masas esencialmente pequeñoburgués, capaz de diezmar y desmoralizar mediante el terror de su fracción más decidida y desesperada a la franja más consciente del proletariado, en una institucionalización de la guerra civil ${ }^{36}$.

Trotski reconoció que, a pesar su inicial apoyo por el gran capital, el fascismo (hasta 1928 en Italia y hasta 1933-1934 en Alemania) fue un movimiento político espontáneo, plebeyo en su origen (pequeña burguesía rural y urbana y sectores marginales del proletariado), con una inequívoca caracterización de masas y con un nuevo tipo de dirección, basada en el liderazgo carismático y la omnipresencia de un partido con voluntad aglutinadora a escala nacional: «El fascismo unifica y arma a las masas dispersas. Con despojos humanos organiza cuerpos de combate. Esto da a la pequeña burguesía la ilusión de ser una fuerza independiente. Comienza a imaginar que ella domina realmente el Estado» ${ }^{37}$.

El fascismo-movimiento sería, por tanto, un partido pequeñoburgués un tanto «especial», adaptado a condiciones y tareas particulares, que se opone a los otros partidos burgueses, y en forma más violenta a los partidos obreros, incluida la social-democracia ${ }^{38}$. Sin embargo, Trotski advierte que, una vez vencido el proletariado, el fascismo-régimen renunciaba a su inicial componente pequeñoburgués en aras de su fusión con el aparato estatal, lo que no estaría en condiciones de producirse más que cuando las formas más extremistas de la demagogia plebeya desaparecieran junto con sus dirigentes de la superficie política y de la ideología oficial ${ }^{39}$.

De mismo modo que señaló lo absurdo de la teoría estalinista que no discriminaba entre regímenes como el de Hitler, Mussolini, Primo de Rivera, Masaryk o Dollfuss, Trotski rechazó en esencia la interpretación que veía en el fascismo una forma avanzada de bonapartismo. Al igual que Thalheimer, consideraba que entre democracia parlamentaria y fascismo existía toda una serie de formas transicionales pacíficas o violentas. Bonapartismo y fascismo eran, pues, formas de excepción diferentes del sistema capitalista en diferentes coyunturas críticas, aunque desde el punto de vista de la hegemonía social el fas-

36 «What Next?»(IX-1932), en TrOTSKI: El Fascismo, p. 43.

37 «Whiter France?» (9-XI-1934), en TroTskI: El Fascismo, p. 99.

38 «El movimiento obrero internacional» (19-XI-1929), en TROTSKI: El Fascismo, p. 63.

39 «El bonapartismo alemán» (10-VI-1933), en TROTSKI: El Fascismo, p. 82.

Hispania, LXI/1, núm. 207 (2001) 17-68 
cismo fuera equivalente al bonapartismo o a la democracia parlamentaria. En realidad, el fascismo era la reacción de la sociedad burguesa a la amenaza específica de la revolución proletaria, y cuando esa amenaza no era inminente, las clases dominantes preferían otras alternativas de gobierno. Con todo, Trotski reconocía la existencia de ciertos elementos de bonapartismo en el fascismo, por ejemplo el aprovechamiento de los viejos antagonismos de clase con el objeto de dar al Estado el máximo de independencia. Pero argumentaba que era diferente el fenómeno bonapartista, que se producía en una época de pujanza burguesa, y el bonapartismo surgido en el período de declive imperialista del capitalismo que condujo a la Gran Guerra, y que con sus formas abiertamente autoritarias actuó como puente histórico hacia el régimen fascista. El fascismo también se diferenciaba del bonapartismo en que la movilización política de masas se producía fuera del control de la élite del poder, y que los regímenes bonapartistas tenían un carácter preventivo que no mostraba el fascismo, el cual tendía a desarrollarse tras una victoria importante de la burguesía sobre el proletariado. Sin embargo, Trotski señalaba que, en su fase de declive, el fascismo abandonaba su inicial demagogia social y podía evolucionar hacia el autoritarismo, transformándose en una forma particular de bonapartismo:

«Una vez llegados al poder, los jerarcas fascistas se ven forzados a amordazar a las masas que les apoyaron, por medio de los aparatos del estado. Por la misma razón, pierden el soporte de amplias masas de la pequeña burguesía. Una pequeña parte es asimilada o integrada en los aparatos burocráticos. Otra se muestra indiferente. Y una tercera, bajo diferentes banderas, pasa a la oposición. Pero mientras pierde su base social de masas, apoyándose en los aparatos burocráticos y oscilando entre las fracciones de clases, el fascismo es regenerado como bonapartismo» 40 .

Aunque nunca reconoció la independencia del Estado fascista respecto de las relaciones de producción capitalistas, Trotski le admitió un cierto grado de autonomía relativa en el proceso dialéctico de la lucha de clases ${ }^{41}$. La gran limitación de su análisis fue contemplar el fascismo como un fenómeno que restringía su acción al ámbito meramente político, minusvalorando las respuestas alternativas que podía ofrecer a la crisis económica mediante la interrelación entre economía, política y administración pública. Los escritos de Trotski tam-

\footnotetext{
40 «Bonapartism and fascism», Bulletin of the Opposition, $\mathrm{n}^{\circ}$ 40, octubre 1934, cit. en TROTSKI, L.: The Struggle against Fascism in Germany and Whiter France?, Nueva York, Pathfinder Press, 1971, p. 441.

41 "Bonapartism and fascism", cit. en TROTSKI: The Struggle against Fascism in Germany and Whiter France?, pp. 437-443. Algunas útiles revisiones de las ideas de Trotski sobre fascismo y bonapartismo, en PASTOR, Manuel: Fascismo y dictadura (Bonapartismo y fascismo), Madrid, Túcar, 1977, pp. 58-69 y 101-110; MANDEL: El fascismo, pp. 33-40 y WISTRICH, Robert S.: «Leon Trotsky's Theory of Fascism", Journal of Contemporary History, vol. XI, no 4, octubre 1976, pp. 157-184. Una discusión general sobre el problema, en DülfFer, Jost: «Bonapartism, Fascism and National Socialism", Journal of Contemporary History, vol. XI, $\mathrm{n}^{\circ} 4$, octubre 1976, pp. 109-128.
}

Hispania, LXI/1, núm. 207 (2001) 17-68 
poco ofrecen una descripción concreta y detallada de los sectores que constituyen esa clase media o pequeñoburguesa insurreccionada que fue el caldo de cultivo del fascismo. Aunque siguió la ortodoxia comunista al describir a los movimientos fascistas como gendarmes del capital financiero, destacó los sacrificios de la gran burguesía por mantener su hegemonía social al precio de la eventual expropiación política. Además, puso más énfasis que otros autores marxistas en las crisis y debilidades del liderazgo proletario para explicar el éxito del fascismo, que interpretaba como el fruto de un triple desmoronamiento: el de la democracia burguesa, la socialdemocracia y los partidos comunistas, sin menospreciar su capacidad para captar las masas de la pequeña burguesía y el proletariado con un liderazgo más ambicioso y eficaz.

Aun reconociendo la objetiva coincidencia entre la acción del fascismo y los intereses de clase de la burguesía capitalista, la socialdemocracia tendió a considerar el desarrollo y la obra política del fascismo como frutos de la dinámica más o menos autónoma de las clases medias. Al igual que Thalheimer, el socialdemócrata austríaco Otto Bauer elaboró una explicación del fascismo tomada directamente del bonapartismo, y reconoció un papel autónomo a la base de masas del fascismo. Un movimiento al que consideraba como una salida entre otras a la crisis del capitalismo, y no como un estadio supremo del mismo en vísperas de su derrumbe, como afirmaba la Comintern. Bauer elaboró una teoría del equilibrio de fuerzas sociales que tiene grandes coincidencias con las de Gramsci, Thalheimer o Trotski. Argumentaba que en períodos donde una clase ascendente acopiaba el suficiente poder social y político para desafiar el de las clases dominantes, el Estado se fascistizaba y conservaba temporalmente la autonomía en relación a las dos grandes fuerzas sociales en presencia: por un lado, un socialismo reformista que había alcanzado gran fuerza en el ámbito laboral, pero cuya actuación dentro del sistema político burgués se había revelado incapaz de seducir a las clases medias empobrecidas y revolucionadas por la crisis, y resistir al tiempo la violencia física del Estado. Por otra parte, una burguesía dueña de los medios de producción y de circulación, instalada de antiguo en el poder estatal, pero incapaz de imponer su voluntad con los recursos legales propios del ordenamiento jurídico democrático, aunque bien dispuesta a formar y equipar «un ejército privado irregular, ilegal y lanzarlo contra la clase obrera»:

«El resultado de este equilibrio de fuerzas, o mejor dicho, de la debilidad de ambas clases, es la victoria del fascismo, que actuando al servicio del capitalismo aplasta a la clase obrera; los mercenarios de los capitalistas llegan a hacerse tan fuertes que aquéllos no tienen otra opción sino cederles el dominio incondicional sobre todo el pueblo, y por tanto sobre ellos mismos también» ${ }^{42}$.

42 BAUER, Otto: «Der Faschismus» (1928), en Zwischen Zwei Weltkriegen? Die Krise der Weltwirtschaft, der Demokratie und des Sozialismus, Bratislava, E. Prager, 1936 (ed. castellana, «El fascismo", en Fascismo y capitalismo, pp. 163-164).

Hispania, LXI/1, núm. 207 (2001) 17-68 
Bauer reconocía que el fascismo era un tipo nuevo de dictadura, y discernió perfectamente la mutación de los apoyos sociales entre su fase de movimiento y su fase de régimen. El fascismo no triunfó en una coyuntura en que la burguesía se viera inminentemente amenazada por la revolución proletaria, sino cuando el proletariado ya se encontraba debilitado y a la defensiva.

Aunque los socialdemócratas culpabilizaron a los comunistas por sus pactos con los nazis, sin preguntarse por las razones del desencanto político de las masas pequeñoburguesas respecto de la socialdemocracia, la moraleja final de Bauer es, precisamente una autocrítica y una admonición al reformismo socialista: «Si creía [la clase obrera] poder utilizar la democracia para edificar el orden socialista, ahora se habrá dado cuenta de que necesita luchar para imponer sobre todo su propia dictadura, con objeto de construir a través de ella un orden socialista que haga posible una democracia total y duradera ${ }^{43}$.

Si los años 1933-1939 fueron «los grandes años de la teoría socialista» ${ }^{44}$, entre fines de la década de los treinta y los cuarenta, el pensamiento marxista crítico vio periclitar la teoría bonapartista bajo el peso de la línea oficial estalinista. No se produjo ningún estudio de relieve, si exceptuamos la obra de Franz Neumann, socialista alemán de izquierda formado en ciencia política en Gran Bretaña y Estados Unidos. En su disección de las bases sociales que apoyaron a Hitler, Neumann desmiente las afirmaciones de los intelectuales adscritos a la tesis del totalitarismo. En su opinión, la esencia del nazismo consistía en «la aceptación y fortalecimiento del carácter clasista que prevalece en la sociedad alemana, en el intento de consolidar a su clase dominante, en la atomización de los estratos subordinados mediante la destrucción de todo grupo autónomo que se interponga entre ellos y el Estado, en la creación de un sistema de burocracias autocráticas que se inmiscuyen en todas las relaciones humanas", rompiendo las solidaridades internas de las "clases dirigidas», pero no eliminando, sino controlando para su beneficio, la estratificación social preexistente ${ }^{45}$.

En su inconcluso ensayo sobre los regímenes democráticos y autoritarios, Neumann definió el fascismo como una dictadura fruto de la tentativa contrarrevolucionaria de clases en franco declive, destinadas a desaparecer ante los cambios radicales en la situación económica y social, que intentan soslayar instaurando un sistema político que garantizase su vieja primacía. Un sistema de poder donde el Estado fundado sobre el imperio de la ley dejó paso al Estadopolicía; donde la dispersión del poder propia de los regímenes liberales se transformó en concentración autoritaria dirigida por un partido único de Estado y un liderazgo carismático; y donde la sociedad de clases fue sustituida por la atomización individual (por ejemplo, la disgregación de la familia), la «sin-

43 BAUER: «El fascismo», en Fascismo y capitalismo, p. 175.

${ }^{44}$ NOLTE: Theorien über den Faschismus, p. 52.

45 NeumanN, Franz: Behemoth. The Structure and Practice of national socialism, Nueva York, Oxford University Press, 1942 (ed. castellana, en Madrid, Fondo de Cultura Económica, 1983, p. 407). 
cronización» de todas las organizaciones sociales y la creación de una jerarquía de élites ${ }^{46}$.

No cabe dudar del calado de las teorías marxistas en comparación con sus competidoras en la época. Pero no lograron aclarar interrogantes básicos, como por qué el fascismo no irrumpió en los países más desarrollados, por qué el gran capital estaría interesado en patrocinar un guerra total que podía destruir sus propios medios de producción, o por qué si la pequeña burguesía estaba amenazada por el capitalismo se asoció con una ideología elaborada y difundida por un partido del que se aseguraba era un agente encubierto del capitalismo financiero. Del mismo modo, tampoco explica de forma satisfactoria el colapso de los trabajadores organizados en $1933^{47}$. Aunque logra establecer una relación plausible entre el sistema capitalista en su conjunto y la creación de condiciones para la génesis y emergencia de los movimientos fascistas, las teorías marxistas no explican bajo qué condiciones algunos sectores de la población apoyan al fascismo, y los procesos mentales y sociales que esa adhesión implica.

\section{LA COARTADA DE LA CLASE MEDIA COMO AGENTE O VÍCTIMA DEL CAMBIO: LAS TEORÍAS DE LA VÍA AUTORITARIA A LA MODERNIZACIÓN}

La concepción del fascismo como un peculiar agente de modernización se había hecho presente en el debate ideológico durante el período de entreguerras, pero el verdadero desarrollo de las teorías de la modernización se produjo tras la Segunda Guerra Mundial de la mano de la sociología y de la ciencia política anglosajonas. Una de las primeras corrientes de análisis social en evaluar la vinculación entre modernidad y fascismo fue la teoría funcionalista, que consideraba este fenómeno como «una forma particular de gobierno que aparece en sociedades entradas en una fase crítica de proceso de transformación social hacia una sociedad industrial, y que, simultáneamente, de forma objetiva o a ojos de la capa dirigente, se sienten amenazados por un levantamiento comunista» ${ }^{48}$. Para Talcott Parsons, el fascismo no resultaba un hecho excepcional, sino un aspecto agravado de la «enfermedad» occidental de la modernización autoritaria. El fascismo extraía lo esencial de su apoyo de la resistencia interpuesta por las élites residuales a las tendencias igualitarias de la sociedad industrial, e introducía la modernidad en el cuerpo social a viva fuerza, llevando la

\footnotetext{
${ }^{6}$ NeumanN, Franz: Demokratischer und autoritärer Staat: Beiträge zur Soziologie der Politik, Frankfurt-am-Main, Europäische Verlagsanstalt, 1967 (ed. castellana, El estado democrático y el estado autoritario: ensayos sobre teoría política y legal, Buenos Aires, Paidós, 1968).

47 Hiden, John y Farquharson, John: Explaining Hitler's Germany. Historians and the Third Reich, $2^{\text {a }}$ ed., Londres, Batsford Academic and Educational Ltd., 1989, p. 159.

48 MOMMSEN, Wolfgang Justin: «Gesellschaftliche Bedingtheit und gesellschfatliche Relevanz historischer Aussagen», en JÄCKEL, Eberhard y WeYMAR, Ernst (eds.): Die Funktion der Geschichte in unserer Zeit, Stuttgart, Klett, 1975, pp. 219-220.
}

Hispania, LXI/1, núm. 207 (2001) 17-68 
anomia a la pequeña burguesía, la juventud, las mujeres y los intelectuales, con procesos como la destrucción de los lazos entre el individuo y su medio social «asignado", la reducción del papel cohesionador de la familia, etc. ${ }^{49}$

La teoría de la modernización que se fue desarrollando en los años cincuenta y sesenta vinculaba la génesis de los regímenes políticos al grado de madurez de su entorno social, económico y cultural, aunque reconocía diversas variantes en cuanto al ritmo del proceso, su continuidad y el grado de sincronía entre las diferentes esferas. Su carácter de proceso multidireccional y reversible (no como la versión marxista del desarrollo capitalista), y su negativa a establecer una vinculación mecánica entre economía y desarrollo sociopólitico la transformaron en un instrumento heurístico muy apreciado para tratar de explicar las causas de los declives democráticos y la aparición de los regímenes autoritarios y totalitarios.

De hecho, el fracaso de la estrategia desarollista en buena parte de los países del tercer mundo cuestionó las teorías de un desarrollo político armónico, y dio lugar a otras que ponían el énfasis en las disfunciones políticas de los procesos industrializadores que se abordaban sin consenso social ni democracia. Dentro del esquema de la modernización, las causas del autoritarismo fueron buscadas, bien en los "puntos de partida» o carencias históricas de la propia transición, bien en la forma en que se produjo ese cambio desde las estructuras feudales a las modernas. Dentro de la primera línea interpretativa, ya en 1935 , Plessner vio a Alemania como un latecomer en el desarrollo, fruto de su incapacidad para llevar a cabo el tipo de revolución burguesa que precedió el desarrollo industrial en Francia o en Inglaterra ${ }^{50}$. Para Ralf Darhrendorf, cada país integraba su proceso de industrialización en su tradición cultural. La de Alemania condujo a un modo de capitalismo feudal-industrial, con un pequeña burguesía refugiada en las estructuras heredadas del Estado dinástico prusiano y sometida a las clases dominantes tradicionales, como la élite autoritaria e iliberal del Imperio. En la Alemania de Weimar, sociedad y democracia tampoco formaron un conjunto homogéneo y armónico. Comprendiendo que la modernización de la sociedad suponía la ruptura de los lazos tradicionales, la alianza de las clases no liberales con la plebe nazi trató de frenar o reconducir ese proceso de modernización, rompiendo para ello las antiguas lealtades sociales. De este modo, el fascismo podía interpretarse como una involuntaria revolución modernizadora con objetivos reaccionarios. Dahrendorf concluye que la ideología nazi era incompatible con la sociedad industrial, pero que a pesar de su ideología antimodernista, las exigencias del poder totalitario convirtieron a

49 PARSONS, Talcott: «Democracy an Social Structure in Pre-Nazi Germany» y «Some Sociological Aspects of the Fascist Movements", en Essays in Sociological Theory Glencoe (Ill.), Free Press, 1954, pp. 124-141 y Società e dittatura, Bolonia, Il Mulino, 1956.

so PlESSNER, Helmuth: Gesammelte Schriften. 6, Die Verspätete Nation. Über die politische Verfübrbarkeit bürgerlichen Geistes, Frankfurt-am-Main, Suhrkamp, 1982 (ed. original, en Stuttgart/Colonia/Mainz, 1959).

Hispania, LXI/1, núm. 207 (2001) 17-68 
los nazis en innovadores radicales en el terreno tecnológico-industrial ${ }^{51}$. Mosse trató de explicar el fenómeno a través del paradójico concepto de «revolución burguesa antiburguesa», ya que, a pesar del apoyo obrero que recibió en países más atrasados, en Italia o Alemania el fascismo fue principalmente una revolución dirigida por la burguesía como escape a sus frustraciones, y con el objeto de que el orden y la propiedad fueran preservados ${ }^{52}$.

Combinando los esquemas de la modernización (entendida como proceso global de transformación económica, social y política hacia una sociedad caracterizada por comportamientos regulados según el esquema normativo de la acción "electiva», frente a la acción "prescriptiva» propia de la sociedad tradicional) y de la movilización (ciclo de aceleración de los cambios sociales, compuesto de varios momentos: integración, ruptura o desintegración, dislocación o transferencia de individuos, grupos o sectores sociales, diponibilidad o movilización psicológica, movilización objetiva y reintegración), Gino Germani distinguió el autoritarismo tradicional del moderno, cuya forma más pura era el fascismo. Las condiciones para la aparición de este último eran, entre otras, un nivel «medio» en la transición económica, social y política hacia una moderna sociedad industrial; la iniciación de ese proceso desde arriba, más que por una revolución de tipo democrático-burgués; la existencia previa de un gobierno democrático representativo; un proceso de integración nacional retrasado o en vías de consolidación y un alto nivel de conflicto entre las clases, que consistiría en una movilización primaria (esto es, producida en el seno de una estructura tradicional) de las clases populares rurales y urbanas, canalizada por sindicatos de tipo socialista, que fue percibida por las élites como una amenaza incontrolable por medios democráticos. En paralelo a este proceso, se inició una movilización secundaria de los sectores dominantes con apoyo de las clases medias más amenazadas en su status material y/o psicológico, que iniciaron esa contramovilización simbólica a través de movimientos políticos que facilitaron una base de masas al fascismo ${ }^{53}$. Éste consistiría, por tanto, en un compromiso entre sectores rurales en declive y la burguesía industrial en ascenso, con intervención de otros potentes elementos que componían el establishment: Iglesia, Ejército, aristocracia, monárquicos y segmentos de las élites intelectuales y profesionales y sectores políticos ideológica, social o vitalmente afines. La meta de la socialización y resocialización planificada por el fascismo era la desmovilización de las clases subalternas y la transformación de toda la población en «militante» ideológico, en participante activo.

Germani señaló que el fascismo europeo podía asumir diversas formas (un Estado totalitario o autoritario) sin perder su esencia política, ya que sus objeti-

${ }^{51}$ DAHRENDorf, Ralf: Gessellschaft und Demokratie in Deutschland, Munich, R. Piper and Co. Verlag, 1965.

52 Mosse, George Lothmann: «Introduction: The Genesis of Fascism», Journal of Contemporary History, vol. I, $\mathrm{n}^{\circ} 1,19.66$, pp. 18 y 22.

53 GermanI, Gino: Sociologia della modernizzazione, Bari, Laterza, 1971, pp. 133-135.

Hispania, LXI/1, núm. 207 (2001) 17-68 
vos eran siempre la consolidación de una situción destinada a reforzar la «desmovilización» de las clases subordinadas, o una ralentización de todos los aspectos de la modernización que pudieran amenazar los intereses de la coalición contrarrevolucionaria en el poder, aun a costa de un prolongado estancamiento económico y social ${ }^{54}$. La estrategia fascista de dominación social no era sino un método no democrático de resover la contradicción entre tradición y modernidad en aquellos países en que las posibilidades inmediatas de desarrollo político y económico tropezaban con circunstancias sociales problemáticas y fuertes elementos internos de oposición y resistencia.

A.F.K. Organski y Barrington Moore Jr. fueron los exponentes más cualificados del grupo de explicaciones que destacaban la diversa evolución de los proyectos modernizadores como elemento determinante para la consolidación de los regímenes políticos. En la vía teórica abierta por Rostow, Organski propuso varios estadios de desarrollo económico capitalista que tenían su reflejo en determinadas configuraciones estatales: 1) Etapa de unificación primitiva, que en el ámbito político se correspondía con el proceso de unificación nacional como prerrequisito del despegue industrial; 2) Preindustrialización, en consonancia con la afirmación en el poder de una nueva clase burguesa; 3) Plena industrialización, que implicaba la transferencia del poder político a una nueva élite industrial, que pacta o combate a las élites tradicionales y crea regímenes de masa, como el fascismo, el estalinismo o la democracia burguesa; 4) Nueva revolución industrial producida por la automatización del proceso productivo, que a nivel político genera la aparición del Estado asistencial, y 5) Estadio político de la abundancia, en el que se habría resuelto el problema de la producción a través de la automatización, y donde el Estado debería afrontar sus consecuencias negativas: desocupación de masas como reflejo de la excesiva concentración del poder económico en el plano de la participación y de la democra$\mathrm{cia}^{55}$. Organski consideraba que el fascismo italiano se identifica con el segundo estadio de desarrollo, mientras que el nazismo sería una de las formas de gobierno típicas del estadio de la plena industrialización. En todo caso, sugería que el potencial de fascismo aumenta en el punto en que el sector industrial de la economía comienza a igualar en importancia y fuerza de trabajo al sector primario, creando el potencial para importantes conflictos sociales que sirven para provocar un nacionalismo agresivo y un gobierno autoritario. El fascismo sería, pues, el resultado de dos desfases básicos de la sociedad en vías de modernización: un rápido desarrollo de la sociedad de masas en países que han comenzado tarde su industralización, pero estuvieron sometidos a violentas

${ }^{44}$ Germani, Gino: Autoritarismo, fascismo e classi sociali, Bolonia, Il Mulino, 1975, pp. 219-225 у $244-247$

55 ORGANSKI, Abraham F. Kenneth: The Stages of Political Development, Nueva York, Alfred A. Knopf, 1965, pp. 14-17. 
presiones sociales en la fase de despegue, y la naturaleza atrasada de las élites y de las instituciones, obligadas a gestionar la salida a esa situación crítica ${ }^{56}$.

Para Organski, el período precedente al ascenso del fascismo se caracterizaba por un rápido desarrollo económico, una vasta movilización social con un importante componente de emigración del campo hacia la ciudad, y una no menos amplia y rápida movilización política, que cobraba la forma de una conflictividad particularmente aguda entre los sectores modernos y no modernos antes de la toma del poder. Opinaba que la élite tradicional mantenía mayores cotas de poder cuando el fascismo lograba el triunfo en estadios más avanzados del proceso de modernización. Una vez establecido el régimen dictatorial, se ralentizaba el ritmo del desarrollo económico y decaía la movilización social, mientras que la actividad política se acrecentaba, por ejemplo entre jóvenes y mujeres $^{57}$. Organski nunca refinó esta teoría de la modernización tardía para hacerla aplicable a Italia o a otros países que sufrieron experiencias de tipo fascista, ya que muchas naciones han pasado por esa etapa de transición sin haber conocido un régimen de esa naturaleza.

En una línea interpretativa similar a la de Organski, Moore señaló tres vías de transición del mundo preindustrial al moderno: la democrático-liberal allí donde la burguesía logró establecer un régimen democrático con el apoyo o a pesar de la resistencia de la aristocracia terrateniente y del campesinado; la comunista-revolucionaria en las situaciones históricas donde el campesinado derribó a la burocracia agraria y se dejó dominar luego por una nueva clase dirigente que debería acelerar el proceso de modernización, y la capitalista-reaccionaria en los lugares donde una burguesía comercial e industrial relativamente débil y dependiente tuvo que aliarse con una parte de las antiguas clases dominantes del campo y la burocracia estatal para crear regímenes políticos conservadores de parlamentarismo limitado (II Reich, Japón Meiji) o democracias efímeras (Weimar), que favorecieron la industrialización respetando la estructura social tradicional. Pero las propias contradicciones de esa modernización conservadora, que no permitió un cambio real de estructuras sociales ni la integración de las masas en la vida pública, hicieron derivar a estos sistemas políticos en regímenes de excepción que permitieron una unificación efímera de las clases altas, y luego en regímenes fascistas como un postrer intento de hacer popular y plebeyo su básico conservadurismo social y económico ${ }^{58}$.

Mientras que Organski interpreta el fascismo como un fenómeno característico de sociedades agrarias que alcanzan un cierto estadio de su transición a

\footnotetext{
56 ReVelli, Marco: «Italy», en MÜHLBERGer, Detlef (ed.), The Social Bases of European Fascist Movements, Londres, Croom Helm, 1987, p. 2.

57 ORGANSKI, A.F.K.: «Fascism and Modernization», en The Nature of Fascism, Londres, Weidenfeld \& Nicholson, 1969, pp. 23-26 y 31-33.

58 MOORE Jr., Barrington: Social Origins of Dictatorship and Democracy, Boston, Beacon Press, 1966 (ed. castellana, Los orígenes sociales de la dictadura y de la democracia. El señor y el campesino en la formación de mundo moderno, Barcelona, Península, 1976, pp. 9 y 351-366).
} 
la modernización, para Moore es el producto de una sociedad agraria en vías de modernización, pero que ha sufrido una serie de vicisitudes políticas previas: no ha conocido sino una "revolución desde arriba», y el cambio ha desembocado en la agitación revolucionaria, temporalmente portadora de modernidad, de una clase fundamentalmente conservadora (el campesinado) abocada a la extinción. De modo que el fascismo sería el punto culminante y conclusivo de esa vía reaccionaria hacia la industrialización, resultado de la intrusión del capitalismo en la economía rural (con la consiguiente crisis del pequeño campesinado) y de las tensiones que surgieron en la fase postcompetitiva del desarrollo capitalista. Una etapa caracterizada por la coalición entre la aristocracia terrateniente, las instancias tradicionales del Estado y una burguesía aún débil, que trataron de modernizar la economía sin comprometer las estructuras sociales.

Moore fue criticado por el fatalismo que dejaba traslucir su análisis de la vía autoritaria a la modernización. En su trabajo, la burguesía es representada como el vehículo natural de la democracia (sobre todo si no existe una poderosa élite terrateniente), pero la democracia aparecía en algunos países como un experimento abocado al fracaso desde los mismos albores de la modernidad, lo que equivale a afirmar que no existían grandes diferencias de matiz entre regímenes autoritarios como el guillermino y el totalitarismo nazi, ya que respondían a un mismo designio de modernización sin cambio social evidente. Hipótesis como la simbiosis alemana entre autoritarismo y nacionalismo, que habría impedido que la revolución burguesa siguiera un modelo democrático, no explican por qué en Italia la robusta tradición liberal y democrática no evitó la implantación del fascismo. Con todo, el mayor mérito del análisis de Moore fue establecer la especificidad histórica y el carácter normal de las diferentes vías a la modernización, además del hecho que estimulara en los años siguientes una amplia gama de investigaciones en política comparada. Por ejemplo, Almond y Powell ensayaron una clasificación de los modernos sistemas políticos movilizados (autoritarismo premovilizado, conservador, modernizante, y totalitarismo conservador y radical) según una escala de diferenciación, secularizción y autonomía de los subsistemas ${ }^{59}$. S.E. Eisenstadt diferenció la modernización «autóctona» y espontánea, propia de Europa Occidental y de los países anglosajones, de la modernización «inducida» que trató de imponerse en unas sociedades con un nivel más bajo de diferenciación social y de desarrollo tecnológico, con una pirámide social mucho más jerarquizada, una base campesina más ancha, unos grupos autónomos (urbanos, religiosos, profesionales o rurales) menos numerosos y unos gobernantes más autocráticos ${ }^{60}$. El fascismo se explica

\footnotetext{
59 Almond, Gabriel Abraham y Powell Jr., G. Bingham: Comparative Politics. A Developmental Approach. An Analytic Study, Boston, Little, Brown, 1966 (ed. castellana, Política comparada, Buenos Aires, Paidós, 1972, pp. 229-235 y 255-262).

60 EISENSTADT, S.E.: Modernization: Protest and Change, Englewood Cliffs, Prentice Hall, 1966 (ed. castellana, Modernización, movimientos de protesta y cambio social, Buenos Aires, Amorrortu, 1972, p. 120).
} 
así como el producto de una ruptura entre las diferentes élites en la manera de gestionar los procesos de industrialización y de modernización ${ }^{61}$. E.A. Shils hizo hincapié en la insuficiente madurez de la infraestructura política de las sociedades sujetas a un cambio acelerado ${ }^{62}$, mientras que David Apter definió el fascismo como un sistema burocrático que surgía como alternativa al sistema de reconciliación liberal y al sistema de movilización democrático ${ }^{63}$. Samuel P. Huntington definió el antimodernismo como ausencia de autonomía, de complejidad, de coherencia y de capacidad de adaptación de la esfera política a los cambios, y estudió el pretorianismo desde el sesgo de regímenes autoritarios modernizantes y desarrollistas con predominio de las oligarquías y de unas clases medias incapaces de constituirse ellas mismas en clases hegemónicas ${ }^{64}$.

En su evaluación de la naturaleza política del nacionalsocialismo, Wolfgang Sauer argumentó que el fascismo era una revolución desde abajo, una revuelta de los declassés (campesinos antiurbanos, empleados, burócratas, pequeños empresarios, profesores, etc.) derrotados directa o indirectamente, temporal o permanentemente, en el proceso de progreso tecnológico y de crecimiento económico, que trataron de invertir el camino de la industrialización retornando a idílicas y naturales formas de vida. De modo que cuanto más industrializada fuera una sociedad, más violenta podría ser la reacción de los perdedores. Ello explicaría la paradoja de un movimiento de masas que protagonizó una revolución social cuyos fines eran antirrevolucionarios en el sentido clásico. Pero al admitir que no existía ninguna alternativa a la sociedad moderna, y al comprometerse con su enemigo industrial, el régimen fascista destruyó las bases de la resistencia tradicional a la modernidad y acabó por destruirse a sí mismo ${ }^{65}$.

Las teorías «no optimistas» la modernización llegaron a alcanzar para muchos no marxistas el mismo poder explicativo que las centradas en la crisis del capitalismo para los marxistas ${ }^{66}$. Sin embargo, presentaban varias debilidades, entre la que no era la menor el establecer una relación dicotómica entre modernidad y tradición, no una acomodación entre una y otra. Al subestimar el dinamismo de una economía capitalista y de una sociedad burguesa llegadas a la madurez, las teorías de la modernización acordaron demasiada importancia a

${ }^{61}$ EISENSTADT: Modernización, movimientos de protesta y cambio social, p. 234.

62 SHILS, Edward Albert: Political Development in the New States, Gravenhage, Mouton, 1962.

63 APTER, David Ernest: Choice and the Politics of Allocation. A Developmental Theory, New Haven, Yale University Press, 1971 (ed. castellana, Una teoría política del desarrollo, México, Fondo de Cultura Económica, 1974).

${ }^{64}$ Huntington, Samuel Phillips: Political Order in Changing Societies, New Haven, Yale University Press, 1968 (ed. castellana, El orden político en las sociedades en cambio, Barcelona, Paidós, 1996, pp. $79-91$ y 175-235) y HunTington, S.P. y MOORE, Clement Henry. (eds.): Authoritarian Politics in Modern Society. The Dynamics of Established one Party Systems, Nueva York, Basic Books, 1970.

65 SAUER, Wofgang: «National-Socialism: Totalitarianism or Fascism?», The American Historical Review, vol. LXXIII, $\mathrm{n}^{\circ}$ 2, diciembre 1967, pp. 404-424, esp. p. 418.

66 GRIFFIN, Roger: «The Search for the Fascist Minimum», en International Fascism, p. 46.

Hispania, LXI/1, núm. 207 (2001) 17-68 
las «tradiciones feudales» en el éxito del fascismo. Situar a éste en un contexto predominantemente agrario no explica de forma satisfactoria los casos italiano o alemán, donde se desarrolló una sociedad altamente industrializada, ni logra matizar la constitución de otro tipo de regímenes autoritarios, como los surgidos en países de industrialización más tardía (donde el peso de los sectores industriales era aún menor, al contrario que los sectores financiero y estatal, que concertaron con los sectores tradicionales alianzas de gran estabilidad para abordar la industrialización sin modificar la estructura agraria) o casi exclusivamente agrarios, donde el proceso modernizador se trató de gestionar casi exclusivamente desde la burocracia del Estado, sometida a un control político total a través de partidos de gobierno en sistemas liberal-oligárquicos y luego en dictaduras militar-corporativas ${ }^{67}$. Vincular los autoritarismos a niveles de desarrollo particulares equivale a postular su carácter inevitable, transitorio y temporal. Por otro lado, la tesis del crecimiento paralelo de la industrialización y de la radicalización fascista es falsa, como se puede constatar en los casos de Francia o Inglaterra, donde el desarrollo político en sentido liberal-parlamentario coincidió con los prolegómenos de la industrialización.

Otro fallo de esta perspectiva es que otorga demasiada trascendencia al tipo de cambio propuesto por las élites dirigentes, y no da suficiente importancia al dinamismo autónomo de los propios movimientos de masas fascistas. Como consecuencia, el fascismo para las teorías de la modernización no es un movimiento autónomo con una clara caracterización social, pequeñoburguesa o no, sino el fruto de una alianza entre élites tradicionales (casi siempre de carácter rural) y una serie de débiles grupos sociales modernizadores, casi siempre sectores mesocráticos de origen urbano.

Aunque la teoría de la modernización adolece de excesiva generalización, ha contribuido a un estudio dinámico del conjunto de la estructura social donde antes campaba la indeterminación de las masas o los análisis socioestructurales de clase de tipo marxista. Como bien señala Bayart, la noción de desarrollo político ya no es patrimonio de ninguna corriente científica particular, puesto que ha sido aplicada de uno u otro modo por liberales, estructofuncionalistas o marxistas, aunque todos ellos han presentado el autoritarismo como una forma política patológica, secundaria y temporal, de régimen de excepción ${ }^{68}$.

\footnotetext{
67 Gómez-Navarro, José Luis: El régimen de Primo de Rivera. Reyes, dictaduras y dictadores, Madrid, Cátedra, 1991, pp. 34-40.

68 BAYART, Jean-François: «L'Analyse des situations autoritaires. Étude bibliographique», Revue Française de Science Politique, vol. XXVI, n 3 , junio 1976, p. 484.
} 


\section{EL REVISIONISMO LIBERAL: CLASES MEDIAS, BUROCRACIA, CONSENSO Y COR- PORATIVISMO EN LA SOCIEDAD FASCISTA}

Las teorías del totalitarismo y de la sociedad de masas entraron en declive a inicios de los sesenta, desbordadas por los estudios de política comparada, que, en consonancia con el nuevo contexto económico y político, aparecían centrados en el desarrollo y la modernización de las sociedades y de los sistemas políticos $^{69}$. Uno de los últimos y más perspicaces teóricos de la sociedad de masas, William Kornhauser, diferenciaba la sociedad de masas de la sociedad totalitaria por la accesibilidad de las élites y por la disponibilidad y organización de las no-élites. Destacaba el atractivo que el carácter irracional de movimientos antidemocráticos y totalitarios como el fascismo tenían para el hombre-masa, cuya existencia podía rastrearse entre los segmentos de población menos integrados en unidades sociales con vida grupal menos independiente, especialmente las clases obreras y las clases medias, aunque dentro de estos estratos, los más receptivos parecían ser aquellos que mantenían menos vínculos socia$\operatorname{les}^{70}$. Como señaló Payne, Kornhauser - y con él todos los estudiosos adscritos al declinante paradigma de la sociedad-masa - olvidaba que el fascismo tenía un programa con llamamientos coherentes a intereses sociales tangibles, y muchos de sus miembros se siguieron identificando y definiendo como miembros de sectores sociales o institucionales estructurados ${ }^{71}$. Al contrario de lo que aseguran las teorías sobre la sociedad de masas, el éxito del fascismo no se debió tanto a su atracción sobre los hombres aislados como al control que sus activistas obtuvieron (mediante una combinación de capacidad, persuasión y violencia) sobre las estructuras intermedias, es decir, sobre las complejas redes de relación social ya existentes, cuyos miembros estaban ideológicamente predispuestos a la militancia en formaciones antidemocráticas de este tipo, pero mantenían una serie de fidelidades básicas que los fascismos lograron destruir. Más que la ausencia de estas redes, fue su resistencia a ser infiltradas, sus estrechos lazos con las Iglesias o con algunos partidos de intereses (como las formaciones campesinas del Norte de Europa) lo que constituyó el mayor obstáculo para el éxito del fascismo en algunos países ${ }^{72}$.

69 Vid., por ejemplo, EASTON, David: The Political System: an Inquiry in to the State of Political Science, Nueva York, Alfred A. Knopf, 1953; Almond, Gabriel A. y COLEMAN, James S. (eds.): The Politics of the Developing Areas, Princeton, Princeton University Press, 1960; MACRuDIs, Roy C. y Brown, Bernard (eds.): Comparative Politics: Notes and Readings, Homewood (Ill.), Dorsey Press, 1968, y ECKSTEIN, Harry y APTER, David E. (eds.): Compartive Politics. A Reader, Nueva York, Free Press of Gencoe, 1963.

70 Kornhauser, William: The Politics of Mass Society, Glencoe, Free Press, 1959, vol. III, pp. 179-182 (ed. castellana, Aspectos políticos de la sociedad de masas, Buenos Aires, Amorrortu, 1969).

71 PAYNE, Stanley G.: Fascism: Comparison and Definition, Madison, University of Wisconsin Press, 1980 (ed. castellana, El fascismo, Madrid, Alianza, 1982, p. 188).

72 LINZ, Juan J.: «Some Notes Toward a Comparative Study of Fascism in Sociological Historical Perspective», en LAQUeUr, Walter: Fascism. A Reader's Guide, p. 42. Vid. al respecto LePSIUS, 
A partir de los años sesenta, el declive del antifascismo militante como criterio historiográfico dominante permitió que las nuevas generaciones de historiadores revisaran las interpretaciones canónicas elaboradas durante la preguerra. Los especialistas no marxistas realizaron unos análisis fundamentalmente descriptivos que descansaban sobre premisas teóricas no claramente definidas, mientras que los marxistas partían de supuestos teóricos claros, pero su aplicación de la teoría se apoyaba en una definición conceptual ambigua, cuando no sobre una casi-tautología ${ }^{73}$.

A mediados de los años sesenta, el concepto de totalitarismo fue dejando paso de nuevo al de fascismo, que había quedado eclipsado una década atrás, en plena Guerra Fría ${ }^{74}$. Los politólogos e historiadores no marxistas lucharon por elaborar nuevas herramientas conceptuales que dieran sentido a un fenómeno que desde la perspectiva de la racionalidad liberal parecía totalmente impredecible. En ese esfuerzo de renovación, la historiografía sobre el fascismo de raigambre genéricamente liberal tuvo tres grandes fuentes de inspiración: la historia fenomenológica de las ideas iniciada por Nolte, las aproximaciones estructurales de la modernización que acabamos de comentar y los análisis estrictamente sociológicos sobre la composición social y la base de masas de los movimientos fascistas y de su electorado ${ }^{75}$. Una nueva generación de estudiosos pudo constatar que las interpretaciones tradicionales eran inadecuadas por su unilateralidad para investigar las bases sociales del fascismo en toda su riqueza de manifestaciones. En consecuencia, los científicos sociales trataron por todos los medios de escapar a la tentación de elaborar interpretaciones excesivamente generalizadoras o monocausales. No sólo historiadores como De Felice trazaron una decisiva divisoria heurística entre el fascismo como movimiento y el fascismo como régimen, sino que se pudo asistir a una doble dinámica de investigación que acabó con la imágen monolítica del fascismo: por un lado, la progresiva individualización y caracterización de cada manifestación nacional del mismo a través de estudios específicos y pormenorizados. Por otro, el análisis de la dinámica interna de los movimientos y sus cambiantes relaciones de fuerza con los grupos sociales. Las líneas preferidas del análisis social de los fascismos fueron en dos direcciones: determinar en su justo término el protagonismo de las clases medias y desentrañar los mecanismos de control de los regímenes fascistas sobre la sociedad, superando los clichés establecidos por las teorías del totalitarismo.

Cuando, a partir de los años cincuenta, se pusieron de moda las hipótesis sobre la modernización, el fascismo pudo ser explicado como hechura de ciertos grupos sociales declinantes como resultado del crecimento industrial y de la amenaza del socialismo y de la democracia de masas. La clase media pareció el

\footnotetext{
Rainer: «The Collapse on an Intermediary Power Structure: Germany, 1933-1934», International Journal of Comparative Sociology, vol. IX, $\mathrm{n}^{0}$ 3-4, septiembre-diciembre 1968, pp. 289-301.

${ }^{73}$ KERSHAW: Qu'est-ce que le fascisme?, p. 76.

74 AYÇOBERRY: La question nazie, p. 202.

75 KERSHAw: Qu'est-ce que le fascisme?, p. 70.
} 
protagonista adecuado para escenificar esta resistencia al cambio: un grupo social heterogéneo, con vínculos de clase suficientemente laxos, situado entre los dos grandes antagonistas del conflicto político de entreguerras, y sin un modelo social claro que proponer como alternativa al liberalismo o al socialismo. La tesis de las clases medias se adecuaba perfectamente a la imagen del fascismo como un movimiento básicamente reaccionario, nostálgico de la estabilidad del pasado y por ende antimoderno. El resentimiento y la desorientación de la clase media podían explicar su apoyo a una ideología que identificaba las razones de su fracaso, y que prometía restaurar su sentido del valor y del mérito.

La tesis de que las clases medias fueron la base social de los movimientos fascistas tuvo su origen en el liberal radical Luigi Salvatorelli, para quien el fascismo fue, además de un movimiento de la pequeña burguesía parasitaria y decadente, desclasada y en riesgo de proletarización, un movimiento de la clase media emergente $^{76}$. El paradigma del fascismo como movimiento eminentemente mesocrático fue asumido en Norteamérica por Harold Lasswell, para quien el nazismo recién llegado el poder era una reacción desesperada y revanchista de las clases medias más pobres, ensombrecidas por la creciente afirmación social y política de los trabajadores y de la alta burguesía ${ }^{77}$. Estas tesis del radicalismo burgués fruto de la crisis en que se veía sumida la sociedad de clases, fueron compartidas en Alemania por Theodor Geiger y ulteriormente por Ralf Dahrendorf $^{78}$. Planeamientos que fueron muy criticadas por Reinhard Bendix, quien en sus primeros estudios de sociología electoral elaborados a mediados de los cincuenta concluyó que el aumento del sufragio nazi se debió más bien a la juventud y a las nuevas masas de votantes de adscripción no necesariamente mesocrática ${ }^{79}$. A su vez, resumiendo resultados más amplios de un estudio sobre la conducta electoral de los alemanes durante el ascenso del nazismo, S.M. Lipset criticó la tesis de Bendix, hasta el punto de aventurar que las ideologías y los grupos extremistas podían ser clasificados y analizados en una perspectiva genealógica con grupos sociales y tendencias políticas «normalizadas» en sentido liberal. En concreto, Lipset señaló tres tipos de extremismo, relacionados con su contrapartida democrática: el de derecha surgido de la clase superior, característico de países de economía atrasada, y que derivaba en tradicionalismo y monarquismo; el de izquierda surgido de la clase obrera en países de industrialización rápida, que derivaba en el socialismo revolucionario, y el centrista de clase me-

\footnotetext{
76 SAlvatoRelli, Luigi: Nazionalfascismo, Turín, Gobetti, 1923 (una ed. reciente, en Turín, Einaudi, 1977).

77 Lasswell, Harold D.: «The Psychology of Hitlerism», The Political Quarterly, 1933, p. 374.

78 GeIGeR, Theodor Julius: Der soziale Schichtung des Deutschen Volkes: Soziographischer Versuch auf Statistischer Grundlage, Stuttgart, Enke, 1967, pp. 349-352 y DAHRENDORF, Ralf: «Demokratie und Sozialstruktur in Deutschland», en Gesellschaft und Freibeit: Zur Soziologischen Analyse der Gegenwart, Munich, R. Piper, 1963, pp. 260 ss.

79 BENDIX, Reinhard: «Social Stratification and Political Power», en BENDIX, Reinhard y LIPSET, Seymour Martin (eds.): Class, Status, and Power. Social Stratification in Comparative Perspective, Nueva York, Free Press, 1966, p. 605 (ed. castellana, Clase, status y poder, Madrid, Euroamérica, 1972).
}

Hispania, LXI/1, núm. 207 (2001) 17-68 
dia, donde el capitalismo y el movimiento obrero ya se habían desarrollado. El fascismo sería un extremismo del tercer tipo, similar al liberalismo en su oposición a los grandes negocios, a los sindicatos y al estado socialista, y en su distanciamiento de la religión y otras formas de tradicionalismo. Para Lipset, este tipo de movimientos respondía a las mismas pautas y necesidades que algunos movimientos liberales convencionales: fueron una salida a las presiones que la estratificación social sometía a las clases medias en un orden industrial maduro, pero en vez de obtener objetivos políticos por la vía reformista, el fascismo resolvía el problema conquistando el Estado y dirigiéndolo hacia una restauración de la seguridad económica de la clase media, para lo cual reducía el poder y el status del gran capital y de los sindicatos. En su análisis de sociología electoral, Lipset comprobó que fueron los miembros independientes de clase media «liberal» (pequeños negociantes, artesanos, profesionales independientes), residentes en pequeñas localidades razonablemente bien integradas y socializadas, y hostiles a la pequeña industria, los que apoyaron la emergencia del nazismo con mayor intensidad que los conservadores tradicionales ${ }^{80}$.

Lipset aplicó el termino «liberal» a grupos sociales que difícilmente pueden ser caracterizados como tales. Además, su tesis parece poco adecuada para analizar la capacidad política y las funciones socioeconómicas de los movimientos fascistas cuando han adquirido el poder. Aunque Lipset no definió el fascismo explícitamente, y sólo se refirió a una manifestación de nacionalismo iliberal y anticomunista con importante apoyo de baja clase media, autores como Nolte asumieron en esencia sus premisas sociológicas sobre el nazismo como un movimiento de clases medias afectadas material y psicológicamente por las distorsiones políticas, económicas y sociales generadas por la modernización en sus versiones liberal-capitalista o socialista-comunista. Aunque también advirtió que el fascismo y el nacional-socialismo supieron ganarse a la alta burguesía y a una parte importante de la clase obrera no revolucionaria ${ }^{81}$.

Juan J. Linz confirmó también la imagen del fascismo como expresión del resentimiento de la baja clase media que rechazaba una identificación con el proletariado ${ }^{82}$. Para Linz, los diferentes sectores sociales se identifican con opciones políticas determinadas, defendidas por partidos, sindicatos y grupos de

${ }^{80}$ LIPSET, S.M.: «Der "Faschismus", die Linke, die Rechte und die Mitte», en Kölner Zeitschrift für Soziologie und Sozialpsychologie, año XI, 1959, pp. 417 ss. (también en "Fascism"-Left, Right, and Center», en Political Man. The Social Bases of Politics, ed. ampliada, Baltimore, John Hopkins U.P., 1981, pp. 127-179).

81 NolTE, Ennst: Der Faschismus in seiner Epoche, Munich, R. Piper \& Co. Verlag, 1963 (ed. castellana, El fascismo en su época. Action Française, Fascismo, Nacionalsocialismo, Madrid, Península, 1967) y Die Faschistischen Bewegungen, Munich, Deutscher Taschenbuch Verlag, 1966 (ed. castellana, La crisis del sistema liberal y los movimientos fascistas, Barcelona, Península, 1971. Utilizamos la ed. francesa: Les mouvements fascistes. L'Europe de 1929 à 1945, París, Calmann-Lévy, 1991, p. 201).

82 LINZ, Juan J.: «Some Notes toward a Comparative Study of fascism in Historical Perspective», en LAQueur, Walter (ed.), Fascism: A Reader's Guide, Berkeley-Los Angeles, University of California Press, 1976, p. 56. 
interés que penetran con mayor o menor éxito en la estructura social. Los partidos fascistas no eran formaciones políticas de ese tipo. No obtuvieron normalmente el apoyo de los grupos sociales a los cuales dirigían su discurso y su acción, y se vieron forzados a llamar, integrar y representar a fuerzas que, en términos de su planteamiento ideológico inicial, no habían esperado estar tan estrechamente identificados con el fascismo. Pero el ideal de integración nacional que éste defendía le impedía rechazar tal apoyo, hasta el punto de desplegar un fuerte eclecticismo ideológico para llamar a todos los estratos sociales, y transformarse así en un "partido atrapatodo" (catch-all party). Como recién llegado a la escena política (latecomer), el fascismo fue además un típico antimovimiento, que definió permanentemente su identidad en confrontación con los partidos, ideologías o valores, que consideraba enemigos, para acentuar de ese modo la voluntad militante de sus seguidores. Pero en la práctica política cotidiana, el fascismo mantuvo un carácter ambivalente de rechazo a las alternativas políticas existentes, combinado con esfuerzos por integrar esas alternativas en una nueva síntesis, con la esperanza de integrar al conjunto de la nación y superar las divisiones de la sociedad moderna expresadas a través de la acción de los partidos. Su éxito dependió del tipo de movimiento y de la particular constelación histórica de fuerzas políticas y sociales existente en cada país ${ }^{83}$.

Renzo De Felice asumió alguno de los conceptos acuñados por Lipset, y describió el fascismo como el vehículo político utilizado por nuevas élites radicales de clase media, distintas de la vieja clase media-alta liberal o de los nuevos proletarios socialistas. El historiador italiano aceptó la importancia de la conexión con las clases medias, pero señaló que esta afinidad no constituía una interpretación comprehensiva del fascismo, sino un fenómeno específico de la historia italiana, y por tanto no generalizable como categoría política a otras latitudes. Según De Felice, el fascismo se afirmó donde era más rápido el proceso de movilidad social vertical y predominaba una economía agrariolatifundista ${ }^{84}$. Pero mientras que el fascismo era un movimiento de la pequeña burguesía emergente, de reciente promoción y deseosa de participación políti$\mathrm{ca}$, en Alemania fue sobre todo obra de las clases medias y pequeñoburguesas ya integradas y en declive tras el crac del $29^{85}$.

En general, las teorías de las clases medias no explican aspectos fundamentales del fenómeno fascista, como los conflictos entre las masas y las élites diri-

\footnotetext{
${ }^{83}$ Sobre el fascismo como latecomer, vid. LINZ, Juan J.: «Political Space and Fascism as a LateComer: Conditions Conductive to the Success or Failure of Fascism as a Mass Movement in InterWar Europe», en LARSEN, Stein Ugelvik, Hagtvet, Bernt y MYKLebust, Jan Peter (eds.): Who Were the Fascists. Social Roots of European Fascism, Bergen/Oslo/Troms $\varnothing$, Universitetsforlaget, 1980, pp. 153-189 y «Some Notes Toward a Comparative Study of Fascism in Sociological Historical Perspective», en LAQUEUR: Fascism. A Reader's Guide, pp. 3-121.

${ }^{84}$ DE FelICE: Le interpretazioni del fascismo, pp. 260 y 24.

85 DE FELICE: Le interpretazioni del fascismo, p. XIII.
} 
gentes, o hasta qué punto el régimen defendió los intereses y las aspiraciones de esas masas de clase media que auparon al fascismo al poder.

Del mismo modo que Mosse caracterizó el fascismo como un movimiento de juventud, no sólo en el sentido de que abarcó un corto espacio de tiempo, sino también en el predominio de una militancia menos madura que la de otros partidos, Merkl señaló que la juventud de los miembros de los partidos fascistas era un rasgo más convincente que la heterogeneidad ocupacional y las amplias diferencias sociales observadas. Los militantes de los partidos fascistas fueron muy jóvenes en comparación con sus antagonistas y predecesores; si exceptuamos a los miembros de los partidos comunistas, hasta el punto de poderse caracterizar como una revuelta generacional, aunque el fascismo en el poder cambiase radicalmente de fisonomía social ${ }^{86}$.

En 1972, Irving L. Horowitz interpretaba el fenómeno fascista bajo una doble faz: mientras que su base de apoyo descansaba en la clase trabajadora, su sistema de poder estaba vinculado a la aparición y el desarrollo de una clase burocrática civil y militar de ámbito nacional, directamente relacionada con las tareas y el aparato del Estado, con una ideología estatalista y conservadora (con rasgos como la reivindicación exclusiva del nacionalismo y el patriotismo, un enfoque de la vida particularmente político y no económico), capacitada en el manejo de la economía y de la sociedad, con intereses definidos e independientes de otras clases, y con una gran capacidad para retar a la clase trabajadora ${ }^{87}$. Horowitz constataba la primacía de la jerarquía y del elitismo sobre la política de masas propia del fascismo, lo que suponía una grave contradicción entre un sistema cuya expresión de fuerza eran las multitudes y cuya estructura organizativa estaba separada de estas masas por factores de rango y posición. Los vínculos sociales tendían a reconstituir la Gemeinschaft feudal, o comunidad popular de destino común, escasamente compatible con la evolución tecnológica del capitalismo. En definitiva, «el fascismo es una etapa en la que los factores de clase en sí se hacen menos significativos que la burocratización y la tecnificación generalizadas de la sociedad» ${ }^{88}$.

En el estricto campo de la organización de las relaciones sociales se ha analizado la función de control y consenso de ciertos elementos institucionales, como la propaganda o el sindicalismo. Un consenso vasto pero no vastísimo, fácil de nutrir con la retórica del progreso social o la falta de éste, con el recurso a sucedáneos irracionales y a mitos pequeñoburgueses proyectados al exterior de la sociedad nacional, como el caso de la raza aria en Alemania y la imagen de la nación proletaria y joven en Italia ${ }^{89}$. Para De Felice, el fascismo elaboró una ideología interclasista, que pretendía actuar como antídoto de la con-

${ }^{86}$ MerkL, Peter H.: «Comparing Fascist Movements», en LARSEN, HaGTVeT y MYKLebust (eds.): Who Were the Fascists, p. 781.

87 HOROWITZ: «Fascismo, un movimiento de masas del siglo XX», pp. 270-272.

88 HorowITZ: «Fascismo, un movimiento de masas del siglo XX», p. 281.

89 DE FELICE: Le interpretazioni del fascismo, pp. 262-263. 
flictividad social. Su llegada al poder fue fruto de un compromiso con la clase dirigente tradicional, y ese carácter de coalición lo mantuvo más allá de 1925 , cuando gran parte de esa élite dirigente decidió seguir sosteniendo a Mussolini para evitar el peligro de un «salto al vacío». La otra opción de poder, postulada por parte del viejo fascismo, hubiera implicado situarse como verdadera alternativa a la clase dirigente tradicional. La prolongada convivencia de esas dos estrategias sociales dio lugar a un régimen con un equilibrio (consenso) sumamente inestable, que se derrumbó definitivamente con la crisis de julio de $1943^{90}$.

Desde los años sesenta, con motivo de los debates sobre el pasado nacional suscitados en Italia y Alemania, se generó una cierta controversia sobre el consenso realmente existente en los movimientos y regímenes fascistas, y por extensión en las dictaduras de entreguerras. El detonante de la polémica fueron las afirmaciones de De Felice sobre la adhesión pasiva existente en Italia entre 1929 y 1934 , lo cual condujo a diversas respuestas, que iban desde la reivindicación de la capacidad modernizadora del Estado fascista como generador de adhesiones (o, como dice Aquarone, su papel como único régimen político en Italia que ha ganado el consenso de las masas al Estado nacional ${ }^{91}$ ), hasta matizaciones sobre la inexistencia de un verdadero consenso porque no hubo una verdadera participación ${ }^{92}$.

En la actualidad se ha llegado a una postura ecléctica, que pone en su justo término la coerción, el papel de la socialización y el alcance de la movilización política más allá de una caracterización monolítica y represiva del Estado fascista ${ }^{93}$. Por ejemplo, la Alltagsgeschichte alemana ha destacado que la gente común se debatía entre el consenso activo, la adecuación y el disenso, y que el sistema de poder nazi era una mezcla compleja de procedimientos coercitivos y de persuasión ideológica: encuadramiento político, propaganda, cultura, enseñanza, política laboral, etc. ${ }^{94}$ De un modo similar, De Felice distinguía entre un consenso activo y pasivo, con toda una serie de actitudes escalonadas que iban en el primer caso desde la resignación al apoyo o la adhesión, y en el segundo desde la desviación y la disidencia a la oposición activa. A diferencia de los sistemas autoritarios de tipo tradicional, la organización del consenso me-

\footnotetext{
90 De FeliCE, Renzo: «Il regime fascista italiano», en la voz «Fascismo» de la Enciclopedia del Novecento, Roma, Istituto dell'Enciclopedia Italiana, 1977, pp. 914-917.

91 Tranfaglia, Nicola: «Fascismo: il regime», en Storia d'Italia, Florencia, La Nuova Italia, 1978, vol. I, pp. 405-437 y AQUARONE, Alberto: Alla ricerca dell'Italia liberale, Nápoles, Guida Editori, 1972, p. 336.

92 QuAZZA, Guido: Resistenza e storia d'Italia. Problemi e ipotesi di ricerca, Milán, Feltrinelli, 1976, pp. 70-104.

93 Sevillano Calero, Francisco: «La organización del "consenso" en las dictaduras de entreguerras», en Propaganda y medios de comunicación en el franquismo, Alicante, Universidad de Alicante, 1998, p. 44

94 Vid. Peukert, Detlev: Volkgenossen und Gemeinschaftsfremde: Anpasung, Ausmerze un Aufbegehren unter dem Nationalsozialismus, Colonia, Bund-Verlag, 1982 (ed. inglesa, Inside Nazi Germany. Conformity and Opposition in Everyday Life, New Haven, Yale University Press, 1987; ed. italiana: Storia sociale del Terzo Reich, Florencia, Sansoni Editore, 1989).
} 
diante instrumentos de difusión cultural y de comunicación social fue un aspecto esencial de los regímenes fascistas ${ }^{95}$. Se ha resaltado el carácter mediador de la personalidad carismática del líder fascista en su relación directa con las multitudes y su institucionalización en el Führerprinzip, o la creación de una sociedad jerarquizada como respuesta a la incapacidad de resolver los problemas de adhesión que habían evidenciado las democracias. Para ello no sólo se procedió a la nacionalización de la masas por medios violentos, sino también a través de la difusión de una cultura nacional-popular unificada que en su manifestación más extrema implicaba la transformación del fascismo en religión laica. Como han estudiado Mosse o Gentile, ritos, mitos, eslóganes y coreografías atraían a las masas a su pertenencia colectiva a la patria y a la nación, sacralizando la política mediante una nueva liturgia a través de la cual pudiesen ser superados el desorden cultural, el nihilismo y la anomia privativos de la cultura finisecular ${ }^{96}$.

La meta del fascismo era, a la inversa del socialismo, fundir los intereses de clase o atemperar el conflicto de clase por medio de la acción del Estado en dos niveles: la sublimación del pueblo y las interpelaciones a su unidad con el fomento de valores antielitistas, inmateriales, nacionalistas y masivos (situados más allá de la naturaleza y de la historia) como la nación, el pueblo o la raza. Los regímenes fascistas trataron de eliminar la separación entre el Estado liberal y las masas (es decir, hacer entrar a las masas en el Estado nacional), y denunciar la incapacidad de la burguesía para dar cabida a una organización amplia del consenso, respondiendo al tiempo a las exigencias de la reorganización económica hacia las formas postcompetitivas del capitalismo organizado. Se trataba de forjar una comunidad nacional ordenada, entusiasta y conquistadora, donde la represión fuera una etapa transitoria para lograr un apoyo popular lo más amplio posible. Pero, en su conjunto, la comunidad nacional se mantuvo como una mera cuestión de propaganda que no modificó sustancialmente el modo en que era vivida cotidianamente la realidad social ${ }^{97}$.

Entre las grandes transformaciones de la sociedad post-liberal se encontraba la planificación autoritaria del sistema social y de los comportamientos individuales en función de los intereses de grupos reducidos que detentaban el control de los aparatos estatales. La negación de la lucha de clases y la forja de un ambiente de solidaridad social se logró a través la adopción de nuevas formas de representación y de negociación continuada de intereses organizados, en

95 Barbagallo, Francesco: «Societat de masses i organització del consens a l'Itàlia feixista», en Franquisme. Sobre resistència i consens a Catalunya (1938-1959), Barcelona, Crítica, 1990, p. 25.

96 MOSSE, G.L.: La nazionalizzazione delle masse. Simbolismo politico e movimenti di massa in Germania (1815-1933), Bolonia, Il Mulino, 1975 y GENTILE, Emilio, Il mito dello Stato nuovo dall antigiolittismo al fascismo, Roma/Bari, Laterza, 1982 e Il culto del Littorio. La sacralizzazione della politica nell' Italia fascista, Roma/Bari, Laterza, 1993.

97 BuRrin, Philippe: «Politique et société: les structures du pouvoir dans l'Italie fasciste et l'Allemagne nazi», Annales ESC, vol. III, 1988, pp. 615-637 (ed. catalana: «Política i societat. Les estructures del poder a l'Itàlia feixista i a l'Alemanya nazi», Afers, n² 25, 1996, p. 500).

Hispania, LXI/1, núm. 207 (2001) 17-68 
concreto el desarrollo institucional del corporativismo. Charles S. Maier ha analizado procesos de redistribución del poder que no pertenecen a ningún régimen concreto, pero que afectan a varios tipos de sistema político. Ha demostrado de forma convincente que la "corporativización» de las estrategias de gestión de los recursos colectivos no fue una empresa exclusiva de los regímenes autoritarios o fascistas, sino que fue un fenómeno que se desarrolló con mayor o menos intensidad en todos los países con vistas a recuperar el equilibrio social perdido con la Gran Guerra. De hecho, el consenso propiciado por el corporativismo consistió unas veces en la represión abierta, y otras en la constante mediación. Las plataformas corporativistas ayudaron a reforzar a las élites de preguerra y a los dirigentes obreros más moderados, pero perjudicaron a las clases medias, menos organizadas ${ }^{98}$. En Italia, esta "defensa corporativista» hubo de ser impuesta por vía coactiva, y se transformó en un sistema jurídico y constitucional con voluntad integral99. Maier achaca el triunfo del fascismo al establecimiento tardío o insuficiente de un sistema corporativo abierto y. pluralista:

«Si Italia hubiera desarrollado antes un corporativismo liberal para sustituir a su antigua estructura parlamentaria y de partidos, el fascismo pudiera haber parecido innecesario para la defensa de la burguesía. Por otra parte, si Alemania no hubiese pasado por la crucial experiencia del capitalismo corporativista, el nazismo hubiera parecido innecesario para la supervivencia de las clases medias. El fascismo italiano vino a llenar un vacío en la arena política y en el mercado de trabajo; el nazismo alemán surgió como descontento contra la organización que en apariencia prevalecía» 100

En todo caso, el consenso forjado por el fascismo era insuficiente y despolitizado, y por tanto frágil. Residía en no tener ninguna oposición, aunque tampoco esperaba adhesiones entusiastas. Como observa Francesco Barbagallo, «el estado totalitario, capaz de integrar la sociedad mediante la solidaridad de clases y el consenso de la población será una aspiración que el fascismo italiano logrará sólo de forma parcial» ${ }^{101}$. Además, esta revisión radical de la modernidad no trataba sólo de obtener el asentimiento popular, sino de crear también un nueva forma espiritual de civilización, cuya tremenda riqueza y manifesta-

\footnotetext{
98 MAIER, Charles S.: Recasting Bourgeois Europe. Stabilization in France, Germany and Italy in the decade after World War $I, 4^{\mathrm{a}}$ ed. revisada, Princeton, Princeton U.P., 1981 (ed. castellana: La refundación de la Europa burguesa. Estabilización en Francia, Alemania e Italia en la década posterior a la I Guerra Mundial, Madrid, Ministerio de Trabajo y Seguridad Social, 1988, p. 31).

99 Sobre la corporativización del Estado fascista vid. CASSESE, Sabino: La formazione dello Stato amministrativo, Milán, A. Giuffrè, 1974 y UVA, Bruno: La nascita dello Stato corporativo e sindacale fascista, Asís-Roma, Carucci, 1974.

100 MAIER: La refundación de la Europa burguesa, p. 720.

101 BARBAGALLO: «Societat de masses i organització del consens a l'Itàlia feixista», p. 24.
} 
ciones no se puede explicar de forma exclusiva en términos utilitarios de consenso $^{102}$.

\section{El REVISIONISMO MARXISTA: UNA NUEVA REIVINDICACIÓN DE LA COMPLE- JIDAD SOCIAL Y DE LA AUTONOMÍA RELATIVA DEL ESTADO FASCISTA}

Aunque tras la guerra se produjeron tentativas de «sutilización» de las teorías socialistas sobre el fascismo, la literatura marxista de posguerra no produjo nada relevante comparado con el impresionante debate abierto en el período anterior. Es más, con la Guerra Fría se produjo un «endurecimiento» del análisis oficial sobre el fascismo, y en el Este se reafirmaron las tesis clásicas del marxismo-leninismo. La historiografía estealemana mantuvo la grosera ecuación fascismo $=$ capitalismo monopolista de Estado (Stamokap), aunque ésta se hizo más compleja, erudita y matizada, sobre todo en lo referente a los límites de la alianza de poder concertada entre las diversas fuerzas antimarxistas, o a la caracterización del fascismo como una salida excepcional a la crisis, lo que reforzó la idea de que el nacionalsocialismo habría ganado autonomía desde $1936^{103}$.

Hasta fines de los años ochenta, la teoría clásica de la Comintern sirvió de directriz inconmovible a los estudios sobre fascismo en Europa del Este, aunque en el Oeste el pensamiento marxista intentó abordar desde los sesenta una revisión parcial de su comportamiento político que conservara intangibles las hipótesis sobre la crisis socioeconómica que había animado su nacimiento y desarrollo. En esos años se profundizó en la teoría y se trató de refinar las categorías marxistas, sobre todo en la dirección de una mayor complejidad en el análisis de la estructura de las clases dominantes, despachada en el pasado con los términos de «contradiciones internas del bloque en el poder» o de «autonomía relativa del Estado». Mientras que el marxismo "vulgar» había concebido el fascismo como una emanación directa del capitalismo y lo reputaba como idéntico a él en sus intereses, los análisis más sofisticados de la posguerra fría fueron reconociendo al fascismo una dinámica crecientemente autónoma, aunque siguieron definiendo el fenómeno bajo el paradigma de su manipulación por parte de los agentes del capitalismo (fueran la pequeña burguesía, el capital financiero, los grandes negocios, las clases industriales, o el capitalismo monopolista de Estado) para satisfacer sus propios fines.

102 Vid. particularmente SCHNAPP, Jeffrey T.: «Epic Demostrations: Fascist Modernity and the 1932 Exhibition of the Fascist Revolution», en Golsan, Richard Joseph (ed.), Fascism, Aesthetics and Culture, Hanover, University Press of New England, 1992, pp. 1-37, esp. pp. 19-20.

103 Sobre las polémicas historiográficas en ambas Alemanias durante la posguerra y la acogida de la diversas teorías "globales», desde el totalitarismo a la modernización, vid. WIPPERMANN, Wolfgang: «The Post-War German Left and Fascism», Journal of Contemporary History, vol. XI, $\mathrm{n}^{\circ} 4$, octubre 1976, pp. 185-219. 
En Italia, los historiadores de formación marxista incidieron en el carácter de clase del fascismo, y lo percibieron como una desembocadura necesaria en el desarrollo del capitalismo, viendo en el devenir de la democracia italiana una continuidad estructural que ligaba el prefascismo, el fascismo y el postfascismo. Santarelli, Carocci o Candeloro fueron los principales mantenedores de la tesis de la «continuidad de clase» del Estado italiano, aunque a través de un análisis social más complejo ${ }^{104}$. Pero fue Nicos Poulantazas quien abordó la revisión más completa de los viejos temas sobre el fascismo elaborados por las diversas corrientes marxistas en los años de entreguerras. La obra de Poulantzas - síntesis "grandiosa e irritante», a decir de Pierre Ayçoberry- se puede considerar como el postrer intento marxista de un análisis global de la sociedad en los regímenes fascistas, ahora bajo la coartada de la crítica a la doctrina emanada de la III ${ }^{a}$ Internacional.

Poulantzas reprochaba a la Comintern el haber abandonado el método dialéctico, y el haber propiciado una concepción economicista y lineal del proceso imperialista. Para este autor, el fascismo era una manifestación política específica, una forma particularmente crítica del régimen y del tipo de Estado capitalista de excepción, cuyo origen tenía que ver con la falta de organización política y la crisis de representación propias de ciertas clases (especialmente la pequeña burguesía y el campesinado, que no disponían ni de un partido político ni de una ideología burguesa capaces de ofrecer una imagen unificada de la sociedad) en función de su aislamiento en la lucha económica ${ }^{105}$.

Poulantzas puso en conexión el fascismo con las contradicciones existentes en el interior de la burguesía, en concreto con el triunfo de los intereses industriales y del capital monopolista en un período de crisis económica. En esa coyuntura, la pequeña burguesía habría mostrado un anticapitalismo superficial y retrógrado, tenía miedo a ser proletarizada y rechazaba la idea de una lucha de clases en la que quedase en medio de los dos grandes contendientes, por lo que propugnó la colaboración de clases en aras del interés general o de la patria, e incluso el arbitraje de un Estado situado por encima de los grupos sociales. La clase media, afectada por la crisis de representatividad de los partidos burgueses, emergió como fuerza social y política por medio de los partidos fascistas, y asumió un papel relativamente autónomo en los enfrentamientos con el gran capital $^{106}$. Este proceso de ruptura dialéctica con el parlamentarismo liberal fue definido por Poulantzas con el concepto de «fascistización»: una agudización de la lucha de clases donde la burguesía pasaba a la ofensiva, pero experimentaba una crisis política cifrada en «una situación de profundización y de exacerba-

\footnotetext{
104 SANTARELli, Enzo: Storia del movimento e del regime facista, Roma, Editori Riuniti, 1967, 3 vols.; CAROCCI, Giampiero: Storia del fascismo, Milán, Garzanti, 1972 y CANDELORO, Giorgio: Storia dell'Italia moderna, Milán, Feltrinelli, 1978-1984, vols. VIII-X.

10s Poulantzas, Nicos: Poder político y clases sociales en el Estado capitalista, $23^{2}$ ed., México, Siglo XXI, 1986, pp. 383-385.

106 POULANTZAS: Fascismo y dictadura, pp. 288-289.
}

Hispania, LXI/1, núm. 207 (2001) 17-68 
ción aguda de las contradicciones internas entre las clases y fracciones de clase dominantes». Situación que identificaba con una crisis de hegemonía en la que ningún grupo era capaz de imponer su dirección de forma directa (por sus propios medios de organización y movilización política) o indirecta (mediante el control del Estado) sobre las otras clases y fracciones que constituían el «bloque en el poder» ${ }^{107}$. A pesar de su inequívoco papel como instrumento de dominación económica del gran capital, el Estado fascista gozó de autonomía política relativa, pero no actuó como árbitro neutral de las fuerzas enfrentadas, como el Estado de tipo bonapartista, sino como verdadero organizador de la dominación política.

En su bosquejo de sociología del fascismo, Poulantzas no se desvió del camino recorrido por el marxismo tradicional sino en pequeños matices. Destacaba que los partidos fascistas fueron partidos de masas fuertemente estructrados, cuya base de apoyo (afiliados, militantes y electores) residía esencialmente en la pequeña burguesía, que, con todo, fue junto con el campesinado pobre y modesto la principal víctima económica del fascismo-régimen ${ }^{108}$. En la cuestión del campesinado, Poulantzas rompió con el mito de unidad de clase del mismo modo que hizo Guérin con respecto a la burguesía industrial: en contraposición con los ideólogos del totalitarismo como Carl Friedrich, que vieron una estrecha relación entre el fascismo y los valores tradicionales del campo, Poulantzas destacó que el fascismo era un fenómeno esencialmente urbano, y que el fascismo rural tuvo un papel claramente subordinado en los países donde se desarrolló. Su presencia en el campo fue como movimiento ideológico-militar directamente vinculado a la gran propiedad agraria ${ }^{109}$. En contraste con teóricos de la modernización como Moore, para quien el campesinado, desorientado políticamente y sometido a la influencia ideológica postfeudal de la gran propiedad, fue presa fácil del fascismo, Poulantzas observó que el campesinado medio y el proletariado agrario fueron los grupos menos permeables al fascismo. Por el contrario, destacó que el campesinado subalterno tuvo gran presencia en movimientos políticos de masa reaccionarios de Europa Oriental, como la Hungría de Horthy o la Rumanía de Antonescu, e incluso en la España de Franco.

Análisis estrictos de clase como los de Poulantzas nos presentan un cuadro social demasiado estático y previsible. Su obra no pasa de reivindicar formalmente las aportaciones gramscianas sobre las contradicciones brotadas en el seno de la propia burguesía en el tránsito del capitalismo concurrencial al monopolista como origen de la autonomía relativa de Estado, pero niega su contenido de fondo, y mantiene la tesis del acceso al poder del fascismo como un mero acto formal que no oculta el predominio social del gran capital. Poulantzas rechazó la tesis bonapartista por considerar que atribuía demasiada auto-

\footnotetext{
107 POULANTZAS: Fascismo y dictadura, pp. 71-72.

io8 POULANTZAS: Fascismo y dictadura, p. 291.

109 PoulantZas: Fascismo y dictadura, pp. 328-329.
} 
nomía y poder al Estado fascista, y empleó el término-fetiche de «fascistización» para ir distribuyendo en torno a él unos roles sociales ya predeterminados por la evolución fatalista del capitalismo hacia una crisis global: el gran capital monopolista como clase hegemónica, la pequeña burguesía de clase reinante a clase mantenedora del Estado totalitario; la clase obrera como clase derrotada y el campesinado como clase marginada. Las relaciones de producción y las diferencias político-ideológicas revisten un papel decisivo en la división de clases y en su actitud respecto del fascismo. Ello supone, especialmente para la pequeña burguesía, un reduccionismo clasista difícilmente asumible en la actualidad, pues asigna un ideología concreta y unas determinadas situaciones en el proceso de producción a todos los representantes de esa clase, que habría actuado al unísono y sin grandes conflictos internos. Además, Poulantzas incurrió en el mismo error de la Comintern al minusvalorar la autonomía relativa del partido y del Estado fascistas (la reconoció, pero sólo para restablecer la dominación del capital monopolista), olvidando los fenómenos de ascenso social y de reparto del poder que se produjeron en su seno.

Reinhard Kühnl, abanderado de la nueva izquierda opuesta a la ortodoxia estealemana, reivindicó una evolución histórica no lineal, centrada en la confrontación de grupos y clases sociales que defendían intereses y objetivos dispares, cuya composición, emplazamiento, autoconsciencia y juego de interrelaciones sufrieron un cambio constante en el proceso histórico. Su diagnóstico sobre el «equilibrio de clases» coincide en términos generales con el de August Thalheimer: frente a la crisis del liberalismo, cifrada en la creciente contradicción establecida entre democracia política y autoritarismo en la esfera económica, se dieron tres alternativas: el socialismo como extensión de los principios de la democracia política a todos los ámbitos de la sociedad; el estado social o Welfare State que intervendría con medidas de control en el ámbito socioeconómico, y el fascismo como estrategia de supresión de la democracia política.

Kühnl aseguró que el fascismo fue un movimiento popular auténtico, que aspiraba a movilizar y a representar a todos los estratos y a todas las clases sociales $^{110}$. Su composición inicial quedó determinada por el desclasamiento y el desarraigo productos de la guerra y la posguerra, pero a continuación consiguió el favor de amplios sectores burgueses en declive (artesanos, comerciantes) desilusionadas con la socialdemocracia y con los partidos burgueses, de segmentos no organizados de la clase obrera (jornaleros, jóvenes obreros en paro, operarios de pequeñas empresas artesanales en el campo, etc.), y, sobre todo, de la «nueva clase media» surgida en el proceso de industrialización y burocratización estatales: empleados de empresas privadas, funcionarios medios y bajos, profesionales liberales y universitarios. Las aspiraciones de grupos tan heterogéneos

110 KÜHNL, Reinhard: Formen Bürgerlischer Herrschaft, Hamburgo, Rowohlt Taschenbuch Verlag, 1971 (ed. castellana: Liberalismo y fascismo, dos formas de dominio burgués, Barcelona, Fontanella, 1978, p. 141).

Hispania, LXI/1, núm. 207 (2001) 17-68 
fueron canalizadas en provecho de las clases dominantes gracias a la difusión de una ideología conservadora, basada en la exaltación de una comunidad de vida y de destino, el principio de autoridad, la defensa de la propiedad privada (a pesar de ciertos atisbos anticapitalistas), el militarismo y el antisemitismo.

Según Kühnl, el fascismo tuvo de específico el régimen político que inspiró, caracterizado por la independencia del poder Ejecutivo en relación con los intereses de las clases dominantes. Una autonomía relativa que Kühnl definió como la «alianza entre los cuadros dirigentes del partido fascista, que asumen el mando del aparato ejecutivo, y grupos directivos de las viejas clases superiores de la economía, de las fuerzas armadas y del aparato estatal que se someten a la dirección del partido y reciben a cambio la garantía de conservar su posición económica y social» ${ }^{111}$. Las viejas clases superiores de tradición liberal controlaban parte del aparato estatal (ejército, justicia, aparato administrativo), de forma que la dirección fascista intentó construir un Estado paralelo, modelado de arriba a abajo por el partido. El régimen nazi fue un experimento de Estado cualitativamente nuevo, que no concertó una alianza unívoca, sino que estableció varios acuerdos sectoriales: uno con los sectores dominantes tradicionales (Ejército, iglesia, burocracia estatal, nobleza terrateniente) sobre la base de un programa feudal y autoritario, otra con grupos capitalistas rivales entre sí, y al menos hasta 1934 una alianza con la pequeña burguesía, sin contar con el tradicional arbitraje del ejecutivo sobre las capillas del propio partido. Este complejo equilibrio de intereses contrapuestos tanto fuera como dentro del Estado se mantendría de forma inestable hasta el derrumbe final, o al menos hasta el complot elitista de 20 de julio de 1944.

El análisis marxista actual considera que el fascismo no es la desembocadura inevitable del capitalismo monopolista, sino una solución de emergencia a que la burguesía financiera recurrió cuando la forma normal (parlamentaria) de dominio no aseguró el mantenimiento de la relaciones de producción capitalistas. Entre los logros de esta corriente de análisis está el haber señalado que el fascismo no era obra de la fracción más atrasada de la burguesía, sino de la más avanzada. Varios autores no marxistas están de acuerdo en que los partidos fascistas no eran capaces de tomar el poder por sí mismos, y que requerían del apoyo de las clases superiores para lograrlo, como han demostrado Tasca y Seton-Watson (cuando hablan de división del poder o diarquía) para Italia o Broszat para Alemania ${ }^{112}$. Ahora más que nunca se acepta una de las viejas tesis elaboradas por los ideólogos del movimiento obrero socialista: que el elemento esencial del sistema fascista fue el compromiso táctico entre el partido y

111 KÜHNL: Liberalismo y fascismo, p. 250.

112 Seton-Watson, Christopher: Italy from Liberalism to Fascism, 1870-1925, Londres, Methuen, 1967, pp. 700-702 y BroszAT, Martín: Der Staat Hitlers. Grundlegung und Entwicklung seiner inneren Verfassung, Munich, Deutscher Taschenbuch, 1983 ( $1^{\mathrm{a}}$ ed. de 1969; ed. inglesa: The Hitler State: The foundation and development of the internal structure of the Third Reich, Londres/Nueva York, Longman, 1981).

Hispania, LXI/1, núm. 207 (2001) 17-68 
las élites sociopolíticas y económicas tradicionales. La peculiar estructura y el ejercicio del poder fascista tienden a dar apoyo empírico a la «tesis de la alianza», cuya operatividad a la hora de estudiar la contradictoria naturaleza de los movimientos fascistas esta hoy fuera de toda duda.

\section{EL REVISIONISMO «DESARROLLISTA»: EL FASCISMO COMO MODERNIZACIÓN SIN MODERNIDAD}

Las tesis desarrollistas de los años sesenta forjaron la imagen del fascismo como un movimiento antimodernizador apoyado desproporcionadamente en estratos preindustriales, en especial el Kleinbürgertum formado por pequeños granjeros, artesanos independientes, pequeños negociantes, tenderos, oficinistas o funcionarios de baja escala. Ya en los años treinta, Trotski había denunciado el antimaterialismo y el antitecnicismo nazi, pues «las victorias de la técnica sobre la naturaleza significan la victoria del gran capital sobre el pequeño» ${ }^{113}$. Nolte caracterizó la tradición contrarrevolucionaria del fascismo como revuelta contra la secularización, la democratización y la integración internacional propias de la era moderna. En ello radicó su gran paradoja: el ser un régimen revolucionario con un reclamo intenso a valores de tipo tradicional (exaltación de formas de vida premodernas, campesinas, antiurbanas, etc.), pero ambientados en la moderna sociedad de masas ${ }^{114}$.

Los primeros atisbos de investigación social sobre el tema abordaron el estudio de los movimientos europeos de derecha como una forma de oposición a la dinámica modernizadora de la sociedad liberal occidental identificada con los principios de la Revolución Francesa: materialismo racionalista, igualdad, educación liberal, secularización, individualismo, diferenciación social, autonomía pluralista y desarrollo capitalista basado en la urbanización y la industrialización. Se aseguraba que estos movimientos recurrían a una imagen idealizada y nostálgica de la sociedad preindustrial, donde las fuerzas tradicionales definían los roles y valores dominantes. De modo que, como advirtieron Lipset, Nolte o Sauer, el fascismo sería un tipo particular de antimodernismo utópico, producto de una crisis de modernización que se arrastraba en la conciencia europea desde fines de siglo, y una revuelta extrema contra el mundo industrial moderno que se agudizó en los años de la inmediata posguerra ${ }^{115}$. Muchos estudiosos del nacionalsocialismo han identificado la doctrina nazi como la heredera de esa ideología derechista alemana en revuelta cultural y política contra la moderni-

113 «El bonapartismo alemán» (10-VI-1933), cit. en TROTSKI: El Fascismo, p. 77.

114 NOLTE, Ernst: «Zur Phänomenologie des Faschismus», Vierteljabreshefte für Zeitgeschichte, $\mathrm{n}^{\circ}$ 10, 1963, pp. 373-407.

115 TURner, Jr. Henry Ashby: «Fascism and Modernization», World Politics, vol. XXIV, $\mathrm{n}^{\circ} 4$, 1972, pp. 547-564 (también en TuRner, H.A. [ed.], Reappraisals of Fascism, Nueva York, Franklin Watt/New Viewpoints, 1975, pp. 117-139.

Hispania, LXI/1, núm. 207 (2001) 17-68 
dad $^{116}$. Pero la gran pregunta seguía siendo cómo logró el fascismo conciliar las tradiciones nacionales con la cultura, la tecnología y las instituciones políticas y económicas modernas.

El presunto carácter retrógrado del fascismo y su oposición frontal a la modernización son fuertemente criticados por la investigación actual en dos grandes vertientes. En opinión de muchos expertos, el fascismo no retuvo, sino que aceleró el proceso de modernización de las sociedades en que logró controlar el Estado, pero situándose fuera de la ideología progresista ${ }^{117}$. Ya en su famosa «entrevista» de 1975, interpretada por algunos como el punto de partida de la historiografía revisionista italiana ${ }^{118}$, De Felice observó que el fascismo era un movimiento «moderno" por su origen ideológico en los ideales jacobinos de la Revolución Francesa y por los elementos positivos de progreso socioeconómico que introdujo. Para A. James Gregor, el fascismo no fue un fenómeno retrógrado, sino que mantuvo rasgos (futurismo tecnológico, productivismo, expansión de la industrialización italiana y redimensionamiento ecológico) plenamente modernos. Fue más bien el resultado de conflictos generados por las fuerzas de modernización en una sociedad tradicional; tensiones que no pudieron ser resueltas por medio de la democracia liberal. El fascismo aparecería entonces como una dictadura movilizadora de masas de carácter desarrollista (término recogido de Borkenau), que mantuvo algunas características (futurismo, nacionalismo) consideradas como modernizantes, y que empleó antiguas glorias y valores del pasado para movilizar las energías populares en pro de la moderni-

116 Vid. la obra clásica de LuKÁcs, György: Die Zerstörung der Vernunft, Darmstadt, Luchterhand, 1962 (ed. castellana: El asalto a la razón: la trayectoria del irracionalismo desde Schelling basta Hitler, $2^{a}$ ed., Barcelona/México, Eds. Grijalbo, 1968); PLESSNER, Helmuth: Die Verspätete Nation, Frankfurt, Suhrkamp, 1974; MossE, George L., The Crisis of German Ideology: Intellectual Origins of the Third Reich, Nueva York, Gosset \& Dunlap, 1964; MANNHEIM, Karl: «Conservative Thought», en WOLfF, Kurt H. (comp.), From Karl Mannheim, Nueva York, Oxford University Press, 1971; Conservatism. A Contribution to the Sociology of Knowledge, Londres, Routledge \& Kegan Paul, 1986 y Stern, Fritz: The Politics of Cultural Despair. A Study in the Rise of the Germanic Ideology, Berkeley/Los Angeles, University of California Press y Nueva York, Anchor Books, 1961.

117 Vid., entre otros, PEUKerT: Volkgenossen und Gemeinschaftsfremde; MASON, Tim W.: «Zur Entstehung des Gesetzes zur Ordnung der nationalen Arbeit, vom 20. Januar 1934: Ein Versuch über das Verhältnis "archaischer" und "moderner" Momente in der Neuesten Deutschen Geschichte», en MOMMSEN, Hans (ed.): Internationales Symposium Industrielles System und Politische Entwicklung in der Weimarer Republik (Bochum, 1973), Düsseldorf, Droste, 1974, pp. 22-351; MATZERATH, Horst y VOLKMANN, Heinrich: «Modernisierungtheorie und Nationalsozialismus», en KOCKA, Jürgen (ed.): Theorien in der Praxis des Historikers. Forschungbeispiele und Diskussion, Göttingen, Vanderhoeck \& Ruprecht, 1977, pp. 95-97; SCHÄFER, Hans Dieter: Das Gespaltene Bewusstsein: über deutsche Kultur und Lebenswirklicbkeit, 1933-1945, Munich/Viena, C. Hanser, 1981, pp. 114-162 y BROSZAT, Martín: «Zur Struktur der NS-Massenbewegung», Vierteljabrshefte für Zeitgeschichte, vol. XXXI, n 1,1983 , pp. 52-76.

118 Sobre la polémica suscitada por este texto fundamental, vid. LEDEEN, Michael Arthur: «Renzo De Felice and the Controversy over Italian Fascism», Journal of Contemporary History, vol. XI, $n^{\circ} 4$, octubre 1976, pp. 269-283. 
zación ${ }^{119}$. David Schoenbaum matiza que esa «conversión» a la modernidad no fue deliberada, sino fruto del «acercamiento inevitable entre el movimiento masivo nazi y las élites estatales e industriales que el partido había prometido destruir» 120 .

Desde un punto de vista más general, estas interpretaciones rechazan el mito identificatorio entre sociedad moderna y proceso histórico caracterizado por el desarrollo progresivo de la libertad y de la racionalidad. Se aduce que no existe modernidad en general, sino diversos modelos nacionales de modernización, con resistencias y reacciones provocadas precisamente por ese mismo proceso. Los estudios más recientes sobre los usos de la retórica antimodernista en la racionalización de la industria alemana aportan pruebas de que la ideología nazi estaba mucho más vinculada con la tecnología moderna de lo que señalaban los trabajos anteriores. Al igual que Gregor, Jeffrey Herf ha demostrado la adecuación del fascismo a la industrialización y la modernización de la economía, pero introduciendo importantes matizaciones referidas al contexto histórico previo a ese despegue. Retomando las ideas de Marcuse en su crítica a la racionalidad tecnológica ${ }^{121}$, Herf señala que «los avances científicos y tecnológicos de Alemania ocurrieron sin el beneficio de la tradición vital del liberalismo político» ${ }^{122}$, por la inadecuada y parcial incorporación del pensamiento racionalista ilustrado a la sociedad alemana (una tesis en cierto modo opuesta a la de Talmon), que produjo entre otras consecuencias un divorcio conceptual entre técnica y capitalismo. Una corriente importante dentro de la ideología nazi postuló «una conciliación entre las ideas antimodernistas, románticas e irracionalistas del nacionalismo alemán y la manfestación más obvia de la racionalidad de medios y fines, es decir, la tecnología moderna»123. Este «romanticismo altamente tecnológico», según la conocida frase de Thomas Mann, tuvo su base social en la «revolución conservadora» patrocinada por la Mittelstand alemana, de la que el primer nazismo no fue sino uno de sus impulsores.

En todo caso, la mayor parte de los regímenes fascistas buscaron la potencia técnica y guerrera, sin aceptar sufrir los efectos desestabilizadores del creci-

119 Gregor, A. James: The Fascist Persuasion in Radical Politics, Princeton, Princeton University Press, 1974; «Fascism and Modernization: Some Addenda», World Politics, vol. XXVI, $\mathrm{n}^{\circ} 3$, abril 1974, pp. 370-384 e Italian Fascism and Developmental Dictatorship, Princeton (N.J.), Princeton University Press, 1979. En la misma línea, GARRUCCIO, Ludovico (seud.): L'industrializazione tra nazionalismo e rivoluzione: le ideologie politiche dei paesi in via du sviluppo, Bolonia, Il Mulino, 1969.

120 Schoenbaum, David: Hitler's Social Revolution. Class and Status in nazi Germany, 1933-1939, Garden City, Doubleday, 1966, p. 276.

121 MARCuSE, Herbert: One Dimensional Man. Studies in the Ideology of Advanced Industrial Society, Boston, Beacon Press, 1964 (ed. castellana: El hombre unidimensional: ensayo sobre la ideología de la sociedad industrial avanzada, $2^{\mathrm{a}}$ ed., Barcelona, Ariel, 1987).

122 HeRF, Jeffrey: Reactionary Modernism: Technology, culture and politics in Weimar and the Third Reich, Cambridge, Cambridge U.P., 1984 (ed. castellana: El modernismo reaccionario: Tecnología, cultura y política en Weimar y el Tercer Reich, México, Fondo de Cultura Económica, 1990, p. 9).

123 HeRF: El modernismo reaccionario, p. 18. 
miento urbano e industrial. La modernidad técnica se vinculó así a un sistema de autoridad y de encuadramiento que trataba suprimir los desórdenes de la modernidad social ${ }^{124}$. Esta obsesión por destacar la «modernización sin modernidad» (es decir, la toma de decisiones socioeconómicas generadoras de cambio, pero en un contexto general de filosofía política sustancialmente conservador, jerarquizado y de base racista), como la definió Tim Mason ${ }^{125}$, minusvalora los conflictos internos al respecto, e incluso los caminos divergentes que tomaron algunos regímenes fascistas. Para Alan Cassels existen dos caras del fascismo: modernizadora en ciertos países subdesarrollados pero opuesta a la modernización en países que, como Alemania, ya estaban industrializados. Si el régimen italiano partió de premisas modernistas (por ejemplo, el futurismo) y acabó abrazando una política mucho más tradicionalista (el ruralismo), el nazismo partió de premisas antimodernistas (el mito spengleriano del Blut und Boden), pero terminó impulsando una industrialización y una urbanización muy rápidas ${ }^{126}$. Para Adrian Lyttleton, el fascismo es el resultado de las tensiones que había traído la modernización económica, tanto en la agricultura como en la industria, y se desarrolló más rápido en las zonas más atrasadas ${ }^{127}$.

En definitiva, la política y la cultura fascistas fueron una respuesta, no necesariamente reactiva, a la crisis de la modernidad representada por los valores de la sociedad burguesa que se venía sufriendo desde antes de la primera guerra mundial. Como señala Sternhell, la vía que rechazaba el racionalismo, el optimismo y el humanismo del siglo XVIII no era reaccionaria, sino una revolución de otro tipo, «que quería cambiar la naturaleza de las relaciones entre el individuo y la colectividad sin destruir el ímpetu de la actividad económica» ${ }^{28}$.

\section{El CONTEXTO ACTUAL: RECHAZO DE LOS PARADIGMAS Y RECUPERACIÓN DE LAS GRANDES COMPARACIONES}

A partir de los sesenta, cuando las grandes ideologías que habían dado cobertura a las interpretaciones clásicas del fascismo entraron en crisis, los científicos sociales fueron abandonando el terreno de las grandes teorías, las tipologí-

\footnotetext{
124 Paxton, Robert O.: «Les fascismes. Essai d'Histoire comparée», en $X X^{e}$ Siècle, $\mathrm{n}^{\circ}$ 45, eneromarzo 1995, pp. 5-6.

125 MASON, Timothy W.: La politica sociale del Terzo Reich, Bari, Laterza, 1980 (ed,. original, en Opladen, 1977).

${ }^{126}$ CASSELS, Alan: «Janus: The Two faces of Fascism», Canadian Historial Association Historical Papers, 1969, pp. 166-184 y en TuRNER, Henry Ashby (ed.): Reappraisals of Fascism, Nueva York, New Viewpoints, 1975, pp. 69-92.

127 LYTTLETON, Adrian: «El fascismo en Italia», en CABRERA, Mercedes, Juliá, Santos y MARTín ACEÑA, Pablo (comps.): Europa en crisis, 1919-1939, Madrid, Ed. Pablo Iglesias, 1991, pp. 68-69.

${ }_{128}$ Sternhell, Zeev, SzNAJder, Mario y ASHÉRI, Maïa: The Birth of Fascist Ideology, Princeton, Princeton University Press, 1994, p. 7 (ed. castellana: El nacimiento de la ideología fascista, Madrid, Siglo XXI, 1994).
} 
as y las síntesis fenomenológicas, y optaron por ofrecer explicaciones menos monolíticas y exclusivistas. En casos como el italiano, el paradigma del antifascismo como espacio de consenso común entre las fuerzas de la nueva democracia ha sufrido una fuerte crítica en los últimos años, con la caída de los mitos de la izquierda y la propia crisis de la República Italiana, que arrastró consigo a la Democracia Cristiana y obligó al PCI a una profunda reconversión política. Se achaca a las tesis resistenciales el ver el fenómeno fascista como un hecho excepcional sujeto a una demonización excesivamente simplificadora. Historiadores como De Felice y Bracher han sido los abanderados de esta renovación de los estudios que Ismael Saz ha definido acertadamente como un proceso de demolición, y de redescubrimiento del sujeto fascista, de la cultura, de la ideología y de las masas con cara y ojos ${ }^{129}$.

Los análisis actuales se han trasladado desde las explicaciones exógenas (capitalismo, construcción nacional o modernización) a interpretaciones endógenas, basadas en el estudio de la dinámica interna de los movimientos y regímenes fascistas ${ }^{130}$. Una de las cuestiones más controvertidas sigue siendo - cómo nosu caracterización social. Ya no se tiende a esquematizar el fenómeno insertándolo de forma más o menos forzada en las teorías de masas, del bonapartismo o de la confrontación irreductible entre burguesía, clase media y proletariado, sino que se opta por multiplicar las investigaciones empíricas que fijen de forma sistemática un mínimo de requisitos para caracterizar a posteriori los apoyos sociales al fascismo. Ya en los años setenta, la investigación sobre la sociografía de los regímenes fascistas y autoritarios de entreguerras se enriqueció con un análisis más detallado. Se estudiaron las diversas y contradictorias actitudes de los grupos sociales ante la conquista del poder, hablando sin tapujos de divisiones internas y de un desarrollo histórico, político e ideológico no unitario que obligan al investigador a declinar el objeto de estudio al plural de los «tantos fascismos" del que habla Rainero ${ }^{131}$. Un claro ejemplo de esta nueva forma de investigar fue la reunión celebrada en Bergen (Noruega) en junio de 1974 bajo el patrocinio de la UNESCO, donde un numeroso grupo de científicos sociales debatió en profundidad sobre la sociología de los regímenes fascistas, y cuyo resultado fue el volumen de más de un centenar de ensayos titulado Who Were the Fascists ${ }^{132}$. Desde fines de los setenta, los estudios comparativos del fascismo han proliferado, sin que los especialistas hayan consensuado una definición operativa del mismo. Estos trabajos tuvieron al menos la virtud de romper el consenso hasta entonces existente, desde Salvatorelli a los marxistas, sobre la identificación absoluta entre el fascismo y la pequeña burguesía antimoderna o

\footnotetext{
129 SAZ: «Repensar el feixisme», p. 453.

130 EATWell, Roger: «Towards a New Model of Generic Fascism», Journal of Theoretical Politics, vol. IV, $\mathrm{n}^{\circ} 2,1992$, pp. 174-190.

131 RAINERO, Romain H.: «Tanti fascismi», en Jader JACOBELLI (ed.), Il fascismo e gli storici oggi, Bari, Laterza, 1988, pp. 85-91.

132 LARSEN, HAGTVET y MYKLEBUST (eds.): Who Were the Fascists.
} 
en declive, marginada económica y socialmente, e insegura y en peligro de proletarización. Parece existir un cierto acuerdo sobre la presencia dominante de las clases medias, pero este dato no parece suficiente para explicar la naturaleza del fascismo.

Los estudios sobre el electorado nazi, iniciados desde los setenta con métodos informáticos, demuestran que la clase media baja (especialmente los sectores que sufrieron más directamente la Gran Depresión) había sido un apoyo sustancial pero no único (Kater), y que el nazismo había calado entre los sectores mesocráticos emergentes y las clases altas (que fueron las primeras en desencantarse), y conseguido una sobrerrepresentación de clases medias-altas y algunos sectores de la clase obrera, como los trabajadores cualificados y los artesanos de pequeña empresa, además de los jóvenes. El fascismo nunca adoptó el carácter de un movimiento mayoritariamente pequeñoburgués, excepto en determinadas áreas y épocas. Fue, ante todo, un movimiento generacional que atrajo a jóvenes, excombatientes, estudiantes y parados. De modo que los estudios más recientes confirman una vez más que no hay un modelo único de apoyo al nazismo referido a clase, generación o sexo.

Los fascismos trascendieron las líneas de fractura sociales, hasta transformarse en un auténtico movimiento polimórfico de alcance nacional y de amplia base (Volkspartei), que realmente trascendió la división de clases: integrado en las áreas rurales y urbanas, apoyado por católicos y protestantes, y con superávit de jóvenes y déficit de mujeres, según los trabajos de Mühlberger. $\mathrm{O}$ más bien, como señala Childers inspirándose en Linz, los partidos fascistas tenían las características de un típico partido de protesta multifacético (aunque con más éxito entre los pequeños comerciantes, artesanos y granjeros de la vieja clase media que sufrían el desplazamiento económico vinculado con la moderna sociedad industrial), capaz de recoger todo tipo de descontento, y cuya heterogeneidad social y demográfica era un componente político altamente inestable, como lo demuestra la volatilidad de su electorado ${ }^{133}$. Los nazis y los fascistas movilizaron más bien a elementos de la población que hasta entonces habían permanecido inactivos, y articularon su movimiento en un cúmulo de heterogéneos estratos sociales funcional y jerárquicamente interconectados: un base de masas crecientemente dominada por la presencia de clases medias dependientes, pero no necesariamente productivas.

${ }^{133}$ Kater, Michael H.: The Nazi Party. A Social Profile of Members and Leaders, 1919-1945, Oxford, Blackwell, 1983; Hamilton, R.F.: Who voted for Hitler?, Princeton, Princeton University Press, 1982; MÜHLBERGER, Detlef: «Germany» en MÜHLBERGER, D. (ed.): The Social Basis of European Fascist Movements, Londres, Croom Helm, 1987, pp. 40-139 y Hitler's Followers: Studies in the Sociology of the Nazi Movement, Londres/Nueva York, Routledge, 1991 y CHILDERS, Thomas: The Nazi Voter. The Social Foundations of Fascism in Germany, 1919-1933, Chapel Hill, University of North Carolina Press, 1983; "The Social Bases of National Socialist vote», Journal of Contemporary History, vol. XI, $\mathrm{n}^{\circ} 4$, octubre 1976, pp. 17-42 y "Les classes mitjanes i el nacional socialisme», Afers, $\mathrm{n}^{\circ}$ 25, 1996, pp. 567-584, además de Th. CHilders (ed.): The Formation of Nazi Constituency, 1919-1933, Londres, Croom Helm y Totowa (N.J.), Barnes \& Noble, 1986. 
Lo que está aún en debate es la actitud de inducción, apoyo, tolerancia, distanciamiento (psicológico o real) o disenso pasivo que exhibieran los sectores burgueses, en especial la alta burguesía industrial y agraria, incómoda por la tendencia del Estado a expandir su control sobre la actividad económica, por la tendencia de la élite fascista a transformarse en clase dominante autónoma, y por los efectos perniciosos de la política exterior agresiva sobre algunos sectores productivos. El equilibrio inestable de los medios dirigentes se ha analizado con modelos multipolares. Se han desarrollado investigaciones que matizan e incluso cuestionan la identidad o el vínculo orgánico del fascismo con las clases dominantes preindustriales o industriales. Nuevos estudios señalan las tormentosas relaciones entre fascismo y gran capital ${ }^{134}$, y cobra fuerza la hipótesis del "compromiso autoritario" (la "cartelización» de poder ya advertida por Neumann) como vía intermedia entre las teorías de la dictadura del gran capital y la absoluta autonomía del partido totalitario. En uno de los últimos análisis de política comparada sobre los regímenes surgidos en Europa durante el período de entreguerras, Gregory M. Luebbert destacó que la aparición de los diferentes tipos de sistema político dependió de las condiciones políticas nacionales desde fines del siglo XIX y su distorsión ante la aparición de las masas como nueva fuerza política. De hecho, advierte que «ningún régimen estable hubiera podido formarse en el período de entreguerras si hubiera carecido del apoyo de las masas» ${ }^{135}$. Liberalismo, fascismo y socialdemocracia fueron las tres respuestas que se arbitraron a las demandas políticas y sociales de la clase obrera. Los tres regímenes actuaron como alternativas en el sentido de que derivaban de diferentes grados de éxito liberal y de modelos diversos de participación obrera en la política anterior a la guerra, se apoyaron en diferentes alianzas de clase (hegemonía de las clases medias y cooptación del sector reformista del movimiento obrero en la democracia liberal; alianza de la clase obrera urbana con el campesinado familiar en la socialdemocracia; alianza del campesinado familiar con la burguesía urbana y aplastamiento y corporativización forzada de la clase obrera en los regímenes fascistas y afines), adoptaron diferentes respuestas ante la crisis económica y exhibieron planteamientos éticos muy distintos.

134 Sobre el escepticismo de los empresarios hacia los fines perseguidos por el partido nazi, vid. WINKLER, H.A.: Mittelstand, Demokratie und Nationalsozialismus, Colonia, Kiepenheuer \& Witsch, 1972. En la misma línea, TURNER, Henry Ashby: Faschismus und Kapitalismus in Deutschland, Göttingen, Vandenhoeck \& Ruprecht, 1972 (ed. inglesa, German Big Business and the Rise of Hitler, Nueva York, Oxford University Press, 1985) y Melograni, P.: Gli industriali e Mussolini. Rapporti tra Confindustria e fascismo dal 1919 al 1929, Milán, Longanesi, 1972.

135 LUEBBERT, Gregory M.: Liberalism, Fascism or Social Democracy, Oxford, Oxford University Press, 1991 (ed. castellana: Liberalismo, fascismo o socialdemocracia. Clases sociales y orígenes políticos de los regímenes de la Europa de entreguerras, Zaragoza, Prensas Universitarias de Zaragoza, 1997, p. 15). Una evaluación detallada de esta obra, en CASANOVA, Julián: «Liberalismo, fascismo y clase obrera: algunas contribuciones recientes a la historia comparada de la Europa de entreguerras», Studia Historica-Historia Contemporánea, vol. X-XI, 1992-1993, pp. 101-124.

Hispania, LXI/1, núm. 207 (2001) 17-68 
Allí donde la aparición de estados-nación independientes se produjo en sociedades con partidos liberales débiles, con un alto nivel de presencia campesina pero un nivel bajo de movilización y escasa organización obrera, se establecieron regímenes antirrevolucionarios con un grado diverso de autoritarismo, que garantizaron los intereses agrarios y los de la fracción de la buruesía urbana más vinculada a la burocracia estatal. En las sociedades altamente movilizadas y modernas (léase industrializadas) de Europa Occidental, con un movimiento obrero fuerte, los regímenes iliberales autoritarios se transformaron en dictaduras fascistas institucionalizadas y estables. Pero Luebbert aclara que las diferencias entre fascismo y autoritarismos no son de grado, como podría sugerir una visión unidimensional del desarrollo económico-político, sino que existe una diferencia sustancial de régimen, ya que la dictadura tradicional no supone, como el fascismo o la socialdemocracia, un cambio en la organización política de la sociedad, salvo la supresión de los movimientos disidentes ${ }^{136}$. Según Luebbert, el fascismo se distinguía de la dictadura tradicional que se desarrolló en el Oriente y el Extremo Occidente de Europa por la completa supresión de las instituciones representativas, su mayor cercanía al modelo totalitario, su mayor grado de intolerancia con la disidencia y la oposición, su ideología monopolística y su visión globalizadora del orden social. Aunque gran parte de su argumentación se basó en el desarrollo de unos modelos políticos ideales, Luebbert tuvo el mérito hacer hincapié en las diversas coaliciones sociales alternativas donde antes se destacaba la superioridad analítica de las tesis del desarrollo socioeconómico o de la lucha de clases. Sin embargo, se interesó más por los resultados de esas alianzas y por los cambios de fisonomía de las organizaciones políticas que por la caracterización real de los diferentes regímenes a que dieron lugar.

Durante décadas los científicos sociales han abordado la construcción de una «teoría general» del fascismo que contuviera un núcleo de proposiciones válidas para la descripción y la explicación del fenómeno independientemente de la especificidad de sus contextos nacionales ${ }^{137}$. La variedad de interpretaciones que se han elaborado no hace sino confirmar la imagen del fascismo como fenómeno con múltiples facetas, ninguna de las cuales consigue recrear el conjunto. También durante años se han recopilado ingentes cantidades de datos históricos para capturar el fenómeno en todas sus dimensiones (política, cultural, económica, psicológica, estética o social), acomodando las variaciones nacionales con el mantenimiento de un mínimo de unidad conceptual. Sin embargo, las generalizaciones sobre su base social siguen siendo muy pobres y bastante discutibles. La investigación comparada ha mostrado y sigue mostrando la heterogeneidad del origen social y político de líderes, militantes y votantes. Para calibrar los cambios en la caracterización de clases del fascismo, parece necesario seguir explorando en detalle las mutaciones en el apoyo social

136 LUEBBERT: Liberalismo, fascismo o socialdemocracia, pp. 456 y 463.

137 SACCOMANI: Le interpretazioni sociologiche del fascismo, p. 12. 
de estos movimientos antes y después de sus ensayos por conquistar el poder en solitario o con apoyos externos, analizar las rupturas y continuidades, describir las tendencias de distribución regional de ese apoyo y las funciones sociales de los movimientos fascistas ${ }^{138}$.

En la actualidad no se atisba ninguna teoría capaz de concitar las adhesiones que antaño tuvieron las hipótesis del totalitarismo, la deriva autoritaria del capital monopolista, el bonapartismo o la modernización. Más bien se ha extendido el rechazo a los términos generalizadores, a las impostaciones ideologizantes y a las fórmulas meramente instrumentales o estáticas. A cambio, se intenta profundizar en el análisis del fascismo en el conjunto de su desarrollo histórico, para tratar de individualizar con más nitidez los mecanismos de movilización y las modalidades de su ejercicio del poder. También es preciso estudiar y comprender sistemáticamente los fascismos y los autoritarismos cercanos a su "campo magnético» ( $\mathrm{Ph}$. Burrin) como un fenómeno conjunto en el que sea posible discernir la evolución particular de las diversas manifestaciones nacionales, pero nunca de manera apriorística o esencialista, sino interpretándolas como las posibles alternativas de resolución autoritaria de los problemas que plantea la aparición de sociedades políticas masivamente movilizadas y la reacción contra los pretendidos excesos de la democracia. Ahora más que nunca, el color que caracteriza el estudio del fascismo no es el negro, ni el pardo, ni el azul. Es el gris que llena de tonos inciertos nuestra permanente perplejidad.

\footnotetext{
${ }^{138}$ HaGTVET, Bernt y KÜHNL, Reinhard: «Contemporary Approaches to Fascism: A Survey of Paradigms», en LARSEN, HAGTVeT y MYKLEBust (eds.): Who Were the Fascists; pp. 26-27.

Hispania, LXI/1, núm. 207 (2001) 17-68
} 